\title{
-
}

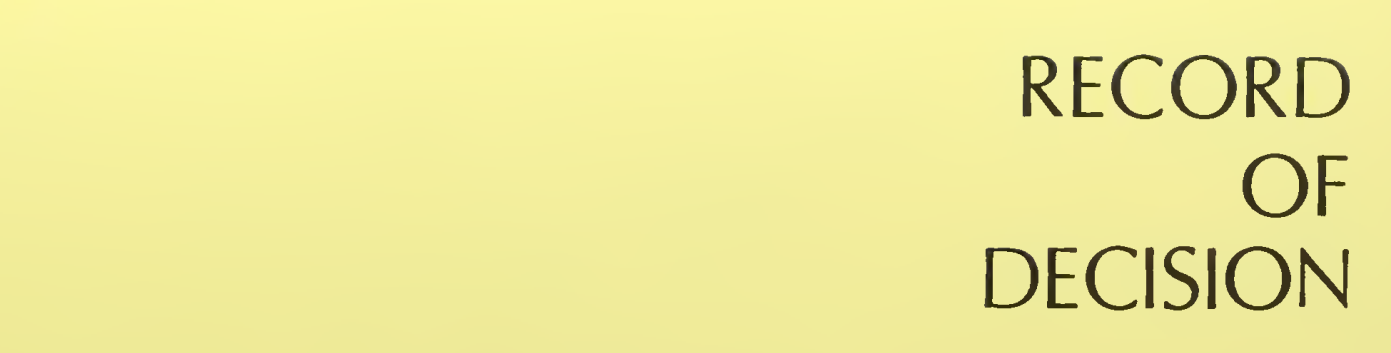

\section{TO THE 1986} PLAN
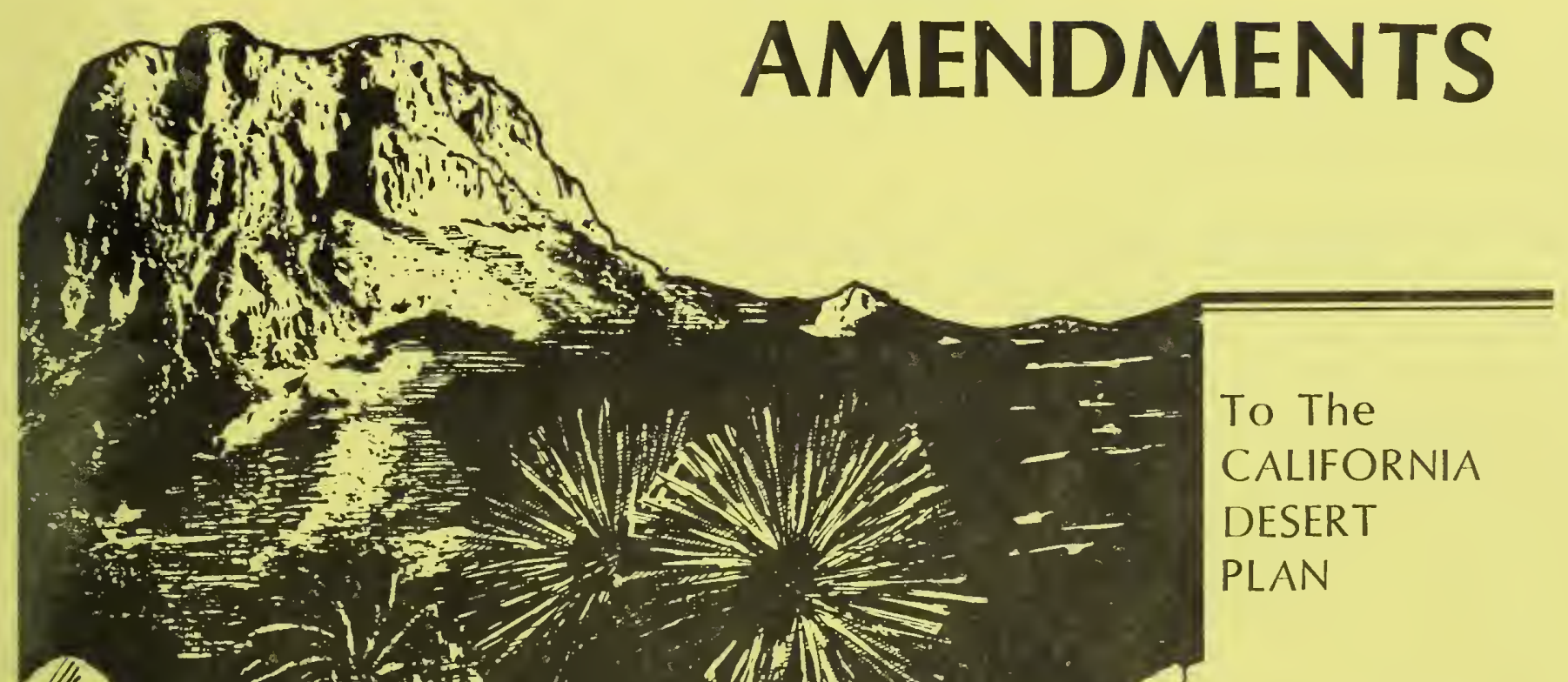

To The

CALIFORNIA

DESERT

PLAN

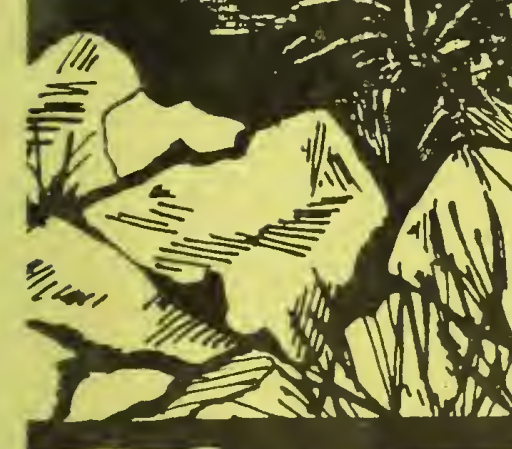

(n)

in

sto

if

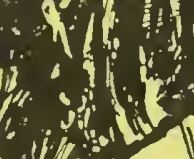

Nitu -20

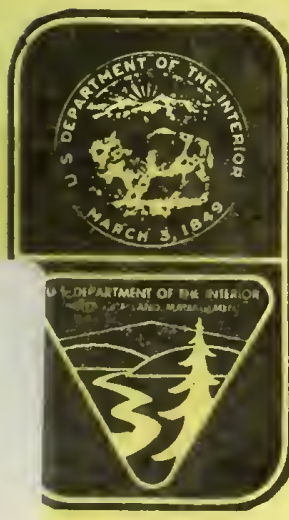

U.S. Department of the Interior

BUREAU OF LAND MANAGEMENT

Riverside, California

December, 1987 



\section{United States Department of the Interior BUREAU OF LAND MANAGEMENT \\ CALIFORNIA DESERT DISTRICT \\ 1695 Spruce Street \\ Riverside, California 92507}

\section{BLM LIBRARY}

Memorandum

To: $\quad$ State Director $(c-910)$

From: District Manager, California Desert

Subject: 1986 Amendment Decision

BLM LIBRARY

SC-324A, BLDG. 50

DENVER FEDERAL CE.

P. 0. BOK 25047

Enclosed is the Record of Decision for the 1986 amendment review of the California Desert Plan indicating my approval of the amendinents.

The enclosed document is provided for your review and concurrence.

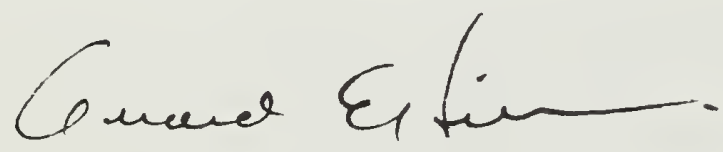

Enclosure

\section{BLA LIBRARY}

I concur with the California Desert District Manager's amendment decisions.

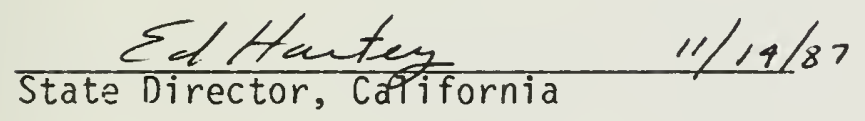


The 1986 amendment review of the California Desert Conservation Area Plan was conducted in accordance with Bureau of Land Management Planning Regulations, (43 CFR 1610.5-5), with the procedures set forth in Chapter 7 of the COCA Plan 1980, and with the Council on Environmental Quality regulations for implementing the National Environmental Policy Act (40 CFR 1500).

During a 30-day period, from February 14 to March 17, 1986, eighteen amendments were proposed by the public and by the BLM staff. These were screened by BLM management and were considered by the California Desert District Advisory Council at a public scoping meeting held on April 10, 1986 in Riverside. Six proposals were accepted for consideration in the environmental assessment (EA). The remainder were rejected or handled through other administrative processes (see Appendix $B$ of the EA).

The public comment period on the EA extended from December 10, 1986 to February 11, 1987. Forty-six written comments were received. Oral comments were accepted at the November meeting of the Advisory Council in Palm Springs.

The preferred alternative for all amendments are the same as those described in the environmental assessment.

The combination of approved amendments comprises the sixth amendment to the Desert Plan. Each component amendment is described below. The environmentally preferred alternative is identified except when there is no significant difference. An overview of public input and responses to specific questions is given in the appendix to this Record of Decision.

\section{Finding of No Significant Impact}

The environimental assessinent identified no significant effects on the human or natural environment. Therefore, an environmental impact statement is not required. 


\section{Proposed Amendment}

Change the boundary of the vehicle closure area in North Saline Valley.

Other Alternatives Considered

No Action (environmentally preferrable alternative)

Decision

Accept proposed amendment with modification. Boundary of the vehicle closure would be changed to exclude route S-014; the rest of the closure would be left unchanged.

\section{Rationale}

Only route $\mathrm{S}-014$ would be opened. It is a 2 mile-long "cherrystern" into WSA 117 and is passable to 4-WD vehicles. Opening this route is expected to have no detrimental effects on the resources of the surrounding area. The other boundary changes were denied, since they would involve opening routes F-030110 and S-0716, both of which are impassable to 4WD vehicles and could not be used without extensive reconstruction which would impair the wilderness quality of WSA 117.

\section{Implementation Needs}

None
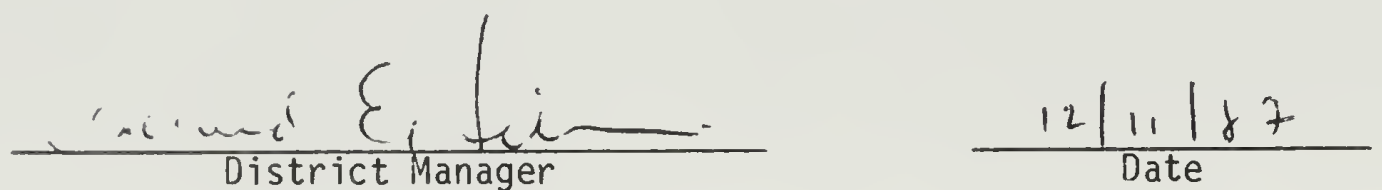


\section{AMENDMENT 1}

BOUNDARY CHANGE

SALINE VALLEY CLOSURE
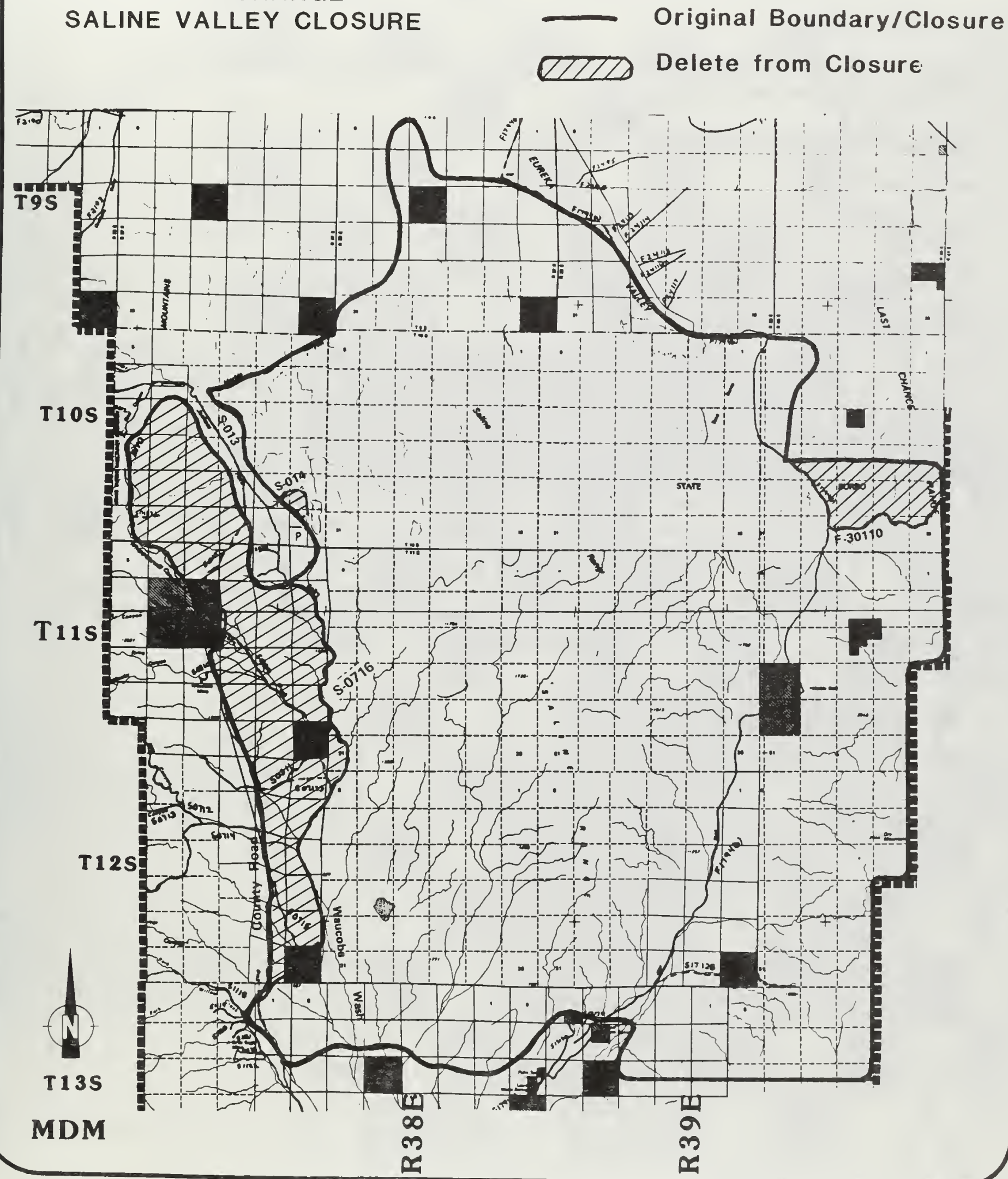


\section{Proposed Amendment}

Change motorized vehicle access designation in the Orocopia Mountains from "closed" to "limited."

\section{Other Alternatives Considered}

No Action

Decision

Accept Proposed Amendment

\section{Rationale}

When this area was designated "closed" in the Interim Critical Management Plan (ICMP) and the COCA Plan, three routes were left open. In subsequent planning actions (the vehicle route designation process and the Orocopia Mountains Habitat Management Plan) all vehicles routes were reviewed, and changes in access were made to improve managability of the area. Two formerly open routes which lead to wildlife water sources were closed on a seasonal basis (June 1 to November 1) for the benefit of bighorn sheep and other wildlife which need unrestricted access to these resources in the summer months. Other routes leading to springs which were closed under the ICMP will remain closed. A few routes were opened; two of these are almost entirely on privately owned land. The Bureau believes this "limited" designation, coupled with guidelines of the Wilderness Interim Management Policy for the Orocopia Mountains WSA, will provide adequate protection for resources and a more appropriate venicle designation.

\section{Implementation Needs}

None

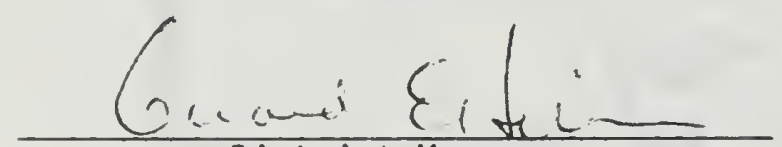

District Manager

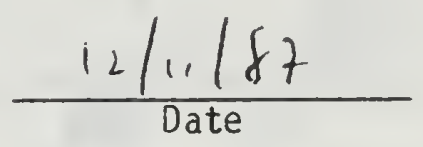




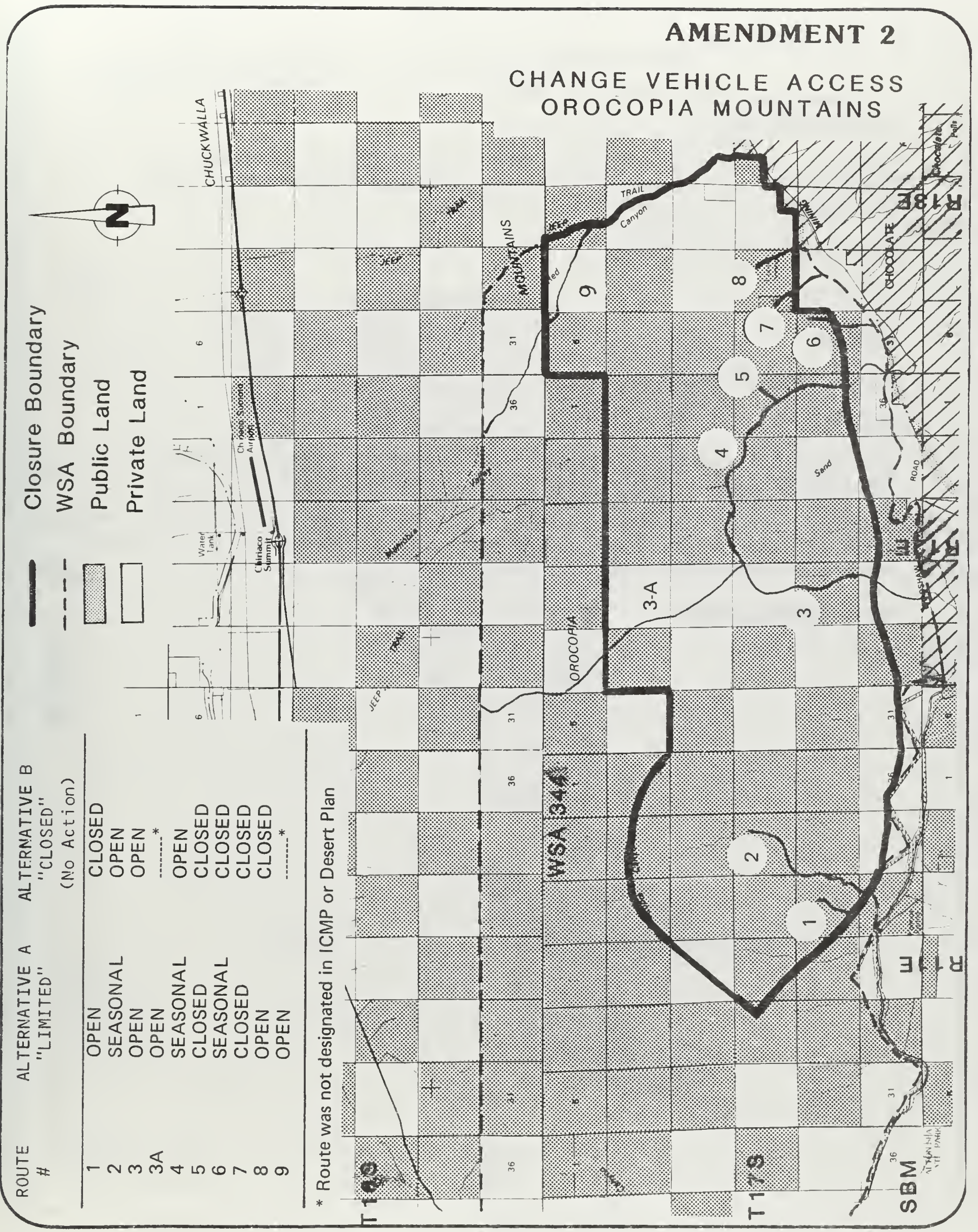




\section{Proposed Amendment}

Modify the boundary of the Saline Valley Area of Critical Environmental Concern (ACEC) as recommended in recently prepared ACEC management plan (environmentally preferable alternative).

Other Alternatives Considered

No Action

Decision

Accept Proposed Amendment

Rationale

The Saline Valley ACEC was designated to provide protective management for significant wildlife habitats (sand dune, mesquite-thicket, meadow and wetland) and prehistoric and historic cultural resources. The area to be added to the ACEC contains important water sources, habitats surrounding the marsh, co-reserve lands owned by the California Department of Fish and Game, and archeological and nistorical sites.

Implementation Needs

None
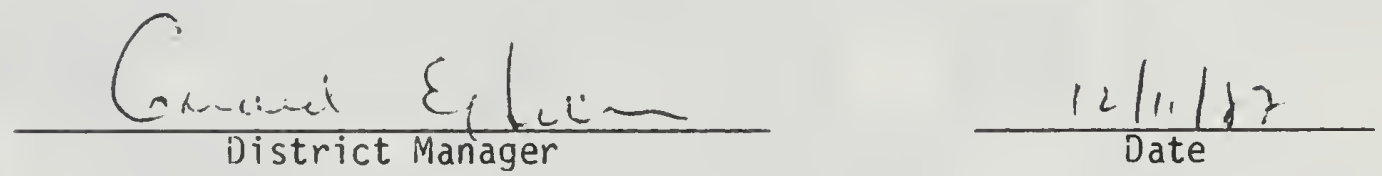


\section{ACEC 4 \\ SALINE VALLEY MODIFY BOUNDARY}

AMENDMENT 3

$\square$ Original ACEC Boundary $\square Z Z$ ACEC Addition

T13S

\section{$T 14 \mathrm{~S}$ \\ MDM}
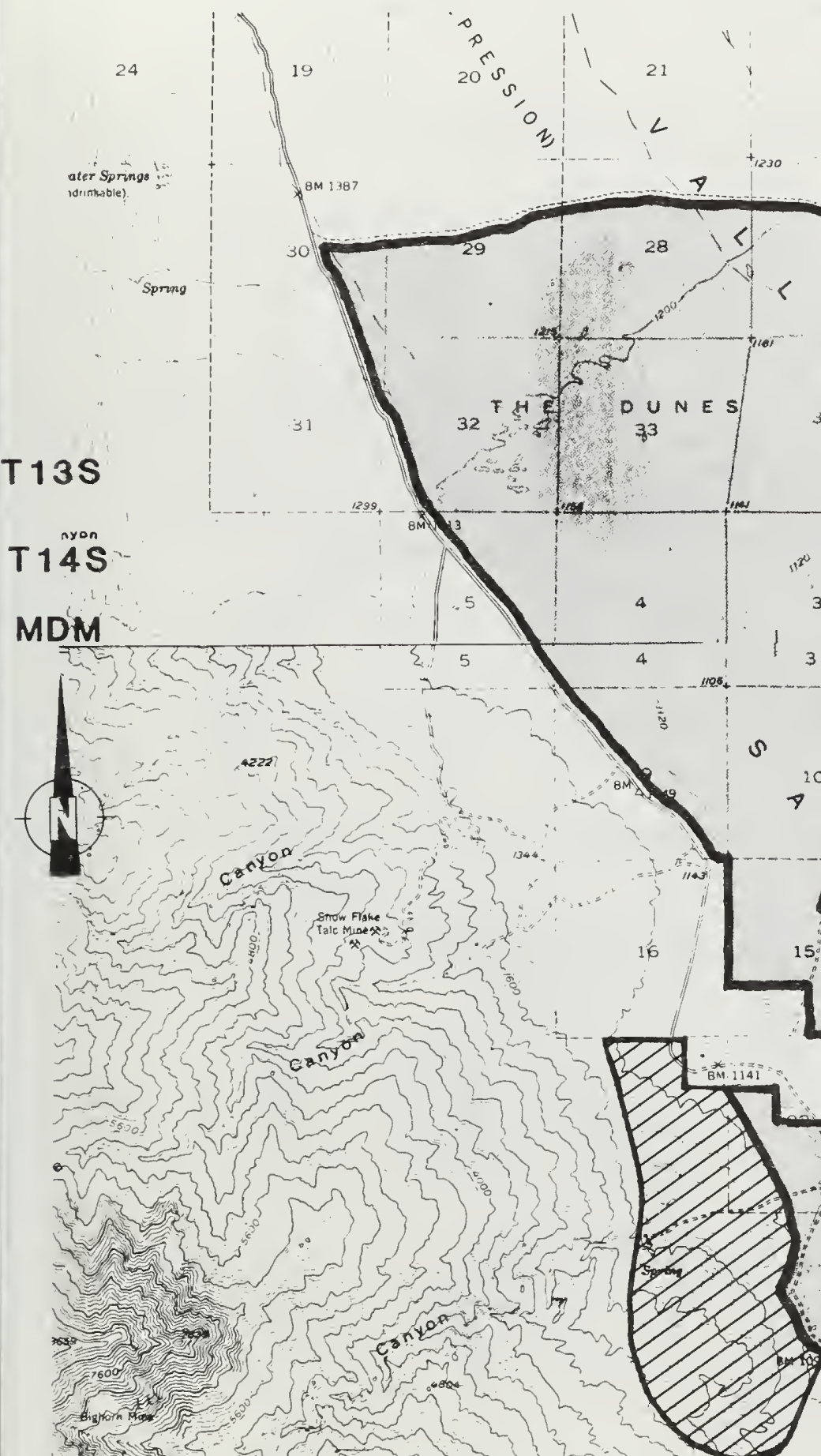
Proposed Amendment

Eliminate the Kramer Herd Management Area (area "J") designation and reduce burro population to zero (environmentally preferable alternative).

Other Alternatives Considered

No Action

Decision

Accept Proposed Amendment

Rationale

Over the past several years, burros have been migrating from the designated herd management area into Edwards Airforce Base, specifically to the east and south sides of Rogers Dry Lake. They are causing damage to archaeological sites, one of which may be eligible for the National Register. In addition, the animals present a potential interference with aircraft operations.

Imp lementation Needs

None
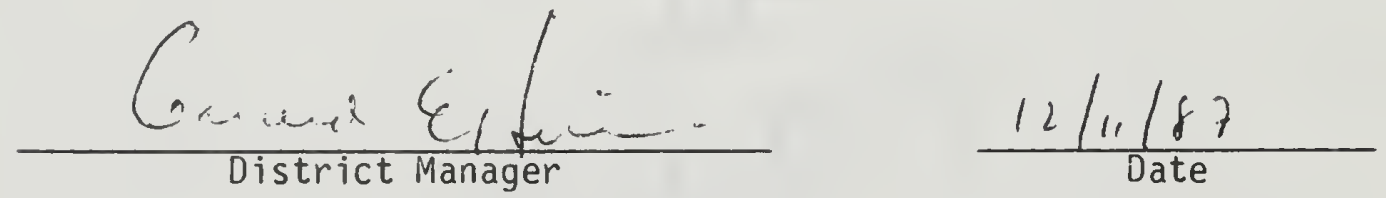
ELIMINATE KRAMER

HERD MANAGEMENT AREA

AMENDMENT 4

(HMA 'J')

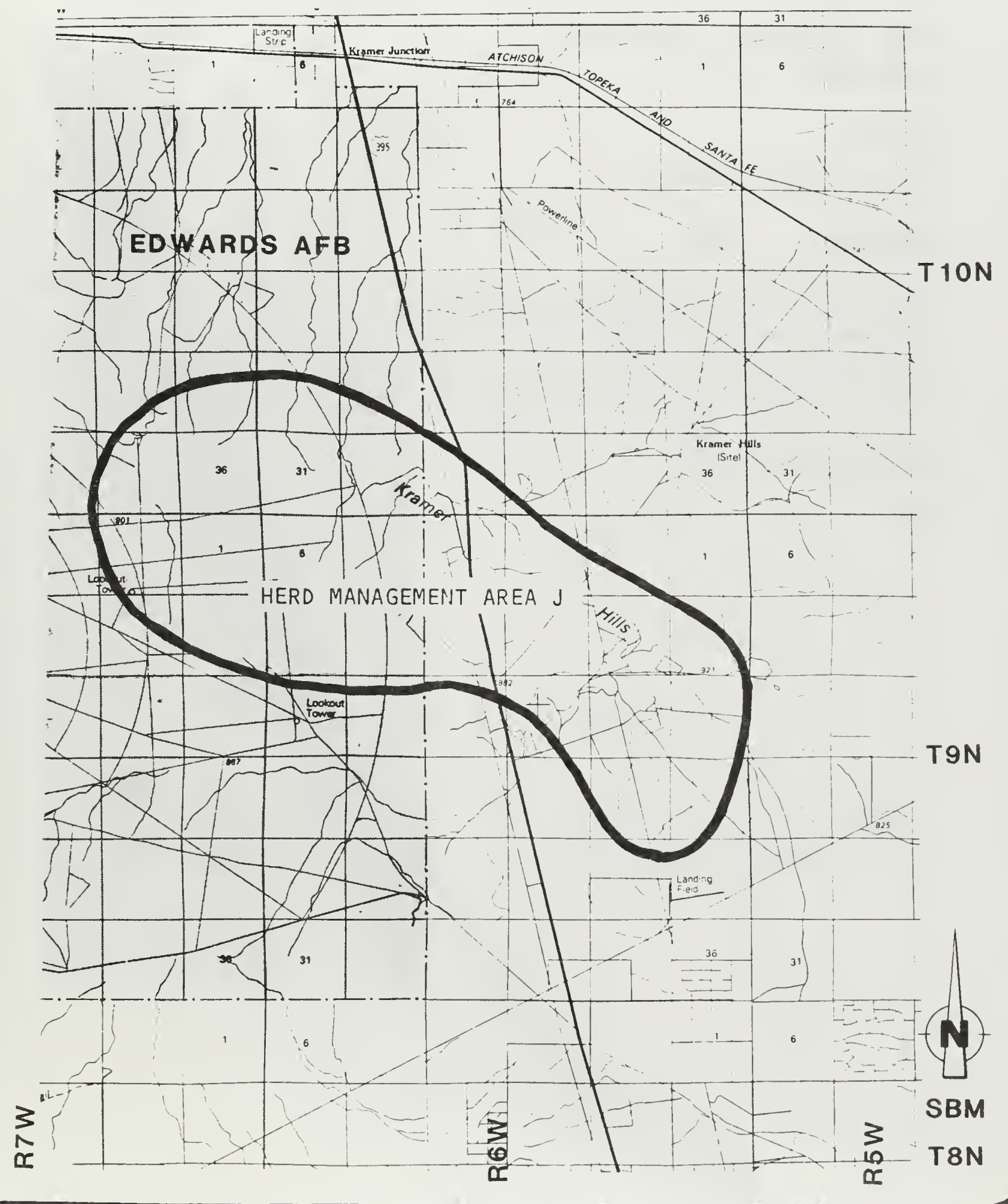


Proposed Amendment

Shift the portion of corridor BB between Zzyzx and Shadow Mountain to the north side of Interstate 15.

Other Alternatives Considered

No Action

Decision

Accept Proposed Amendment

Rationale

This portion of corridor $B B$ is presently within the East Mojave National Scenic Area and is sensitive to the routing of a utility line. The realignment would preclude future utilities from being located within this portion of the Scenic Area. That portion of the amended corridor winich is within wilderness study areas 228 and 242 would not be useable until (and only if) Congress decides not to designate the area as wilderness.

\section{Implenentation Needs}

None
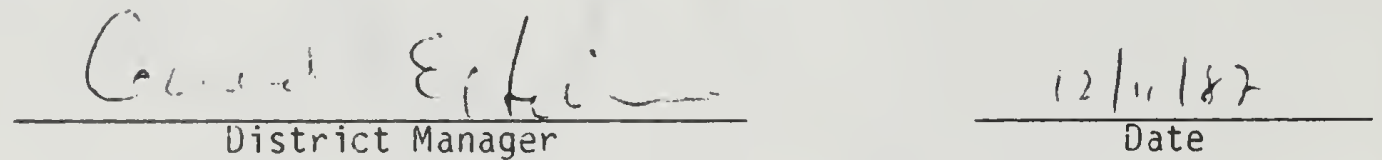


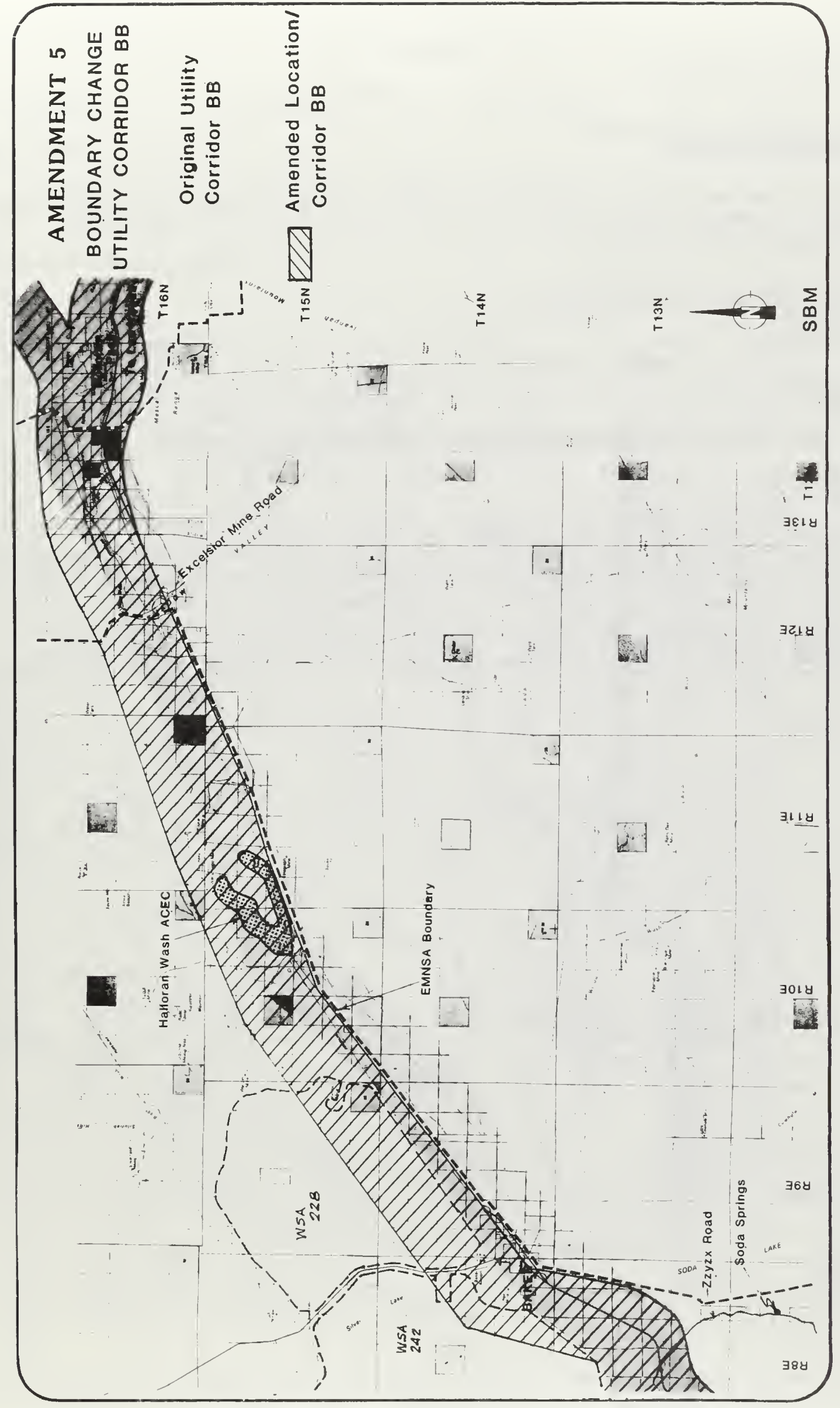




\section{Proposed Amendment}

Within the San Diego County Planning Unit, change tiwo acres of the Carrizo Gorge Wilderness Study Area from Class L to Class C (environmentally preferable alternative).

\section{Other Alternative Considered}

No Action

Decision

Accept Proposed Aineridment

Rationale

The two acres originally designated as Class $L$ were designed to provide off-road venicle access to scenic overlooks within the Carrizo Gorge WSA. Field evaluations conducted since the completion of the Eastern San Deigo County Management Framework Plan have shown that the overlooks were incorrectly mapped; one was outside the WSA and the other was only partiy inside the WSA boundary. Thus, OHV access is not neejed. In addition, proinibiting vehicle access would protect the rare peninsular bighorn sheep.
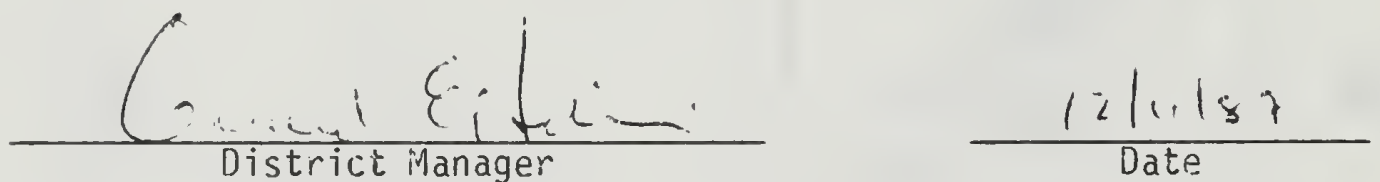
WSA Boundary

Change from " $L$ " to " $C$ " .....

Incorrect Overlook Site *

Corrected Overlook Site
AMENDMENT 6

CARRIZO GORGE WSA

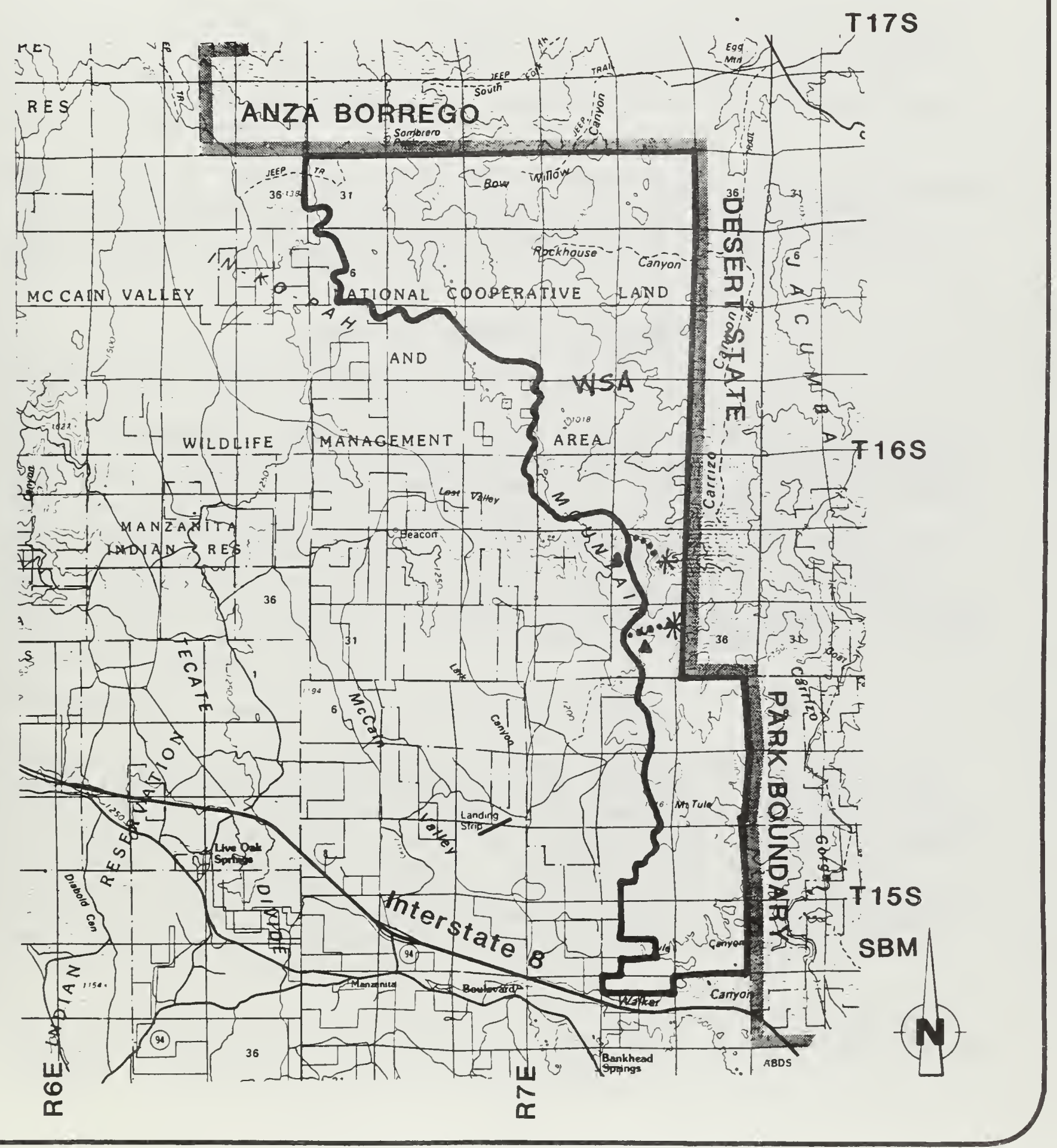


GENERAL OVERVIEW

The environmental assessment on the 1986 Amendments to the California Desert Plan and Eastern San Diego County Management Framework Plan (MFP) was released for public review on December 10, 1986. The comment period extended to February 11, 1987. Forty-six letters were received during that period. An opportunity for oral comment was provided at the California Desert District Advisory Council meeting on November 6,1986 in Palm Springs.

The letters came from the following sources: 25 (55\%) from individuals, 11 (24\%) from organizations, seven (15\%) from governmental agencies, two (4\%) from utilities, and one (2\%) from a business. Nine (20\%) of the respondents were located in the California Desert, 24 (52\%) were in other parts of Southern California, ten (22\%) were in Northern California, and three (60\%) were in other states.

The majority of comments from individuals favored conservation and protection of natural resources and opposed expansion of off-road venicle access. Approximately 30 of the respondents commented on all six of the proposals; others limited their comments to one or a few of the amendments.

\section{SUMMARY OF COMMENTS BY AMENDMENT}

\section{AMENDMENT ONE - VEHICLE ACCESS IN NORTH SALINE VALLEY}

Only one respondent favored Alternative $A$, which would change the boundaries of the North Saline Valley closure to allow vehicle access on several routes. The rest of the comments were almost equally divided between those who wanted to prevent any new venicle access and those who agreed with the Bureau's modification to permit opening of the short route S-014 in the Jackass Flats area. Opposition to the amendment was due to concerns about opening up a route to Death Valley through the Last Chance Canyon Range, with possible endangerment of the habitat of the rare plant Dedeckera eurekensis. There was also opposition to the opening of routes south of the Jackass Flats area due to potential damage by ORVs.

\section{AMENDMENT TWO - VEHICLE ACCESS IN OROCOPIA MOUNTAINS}

A large majority of the comments on Amendment Two opposed the proposal to change the motorized vehicle designation from "closed" to "limited" in the Orocopia Mountains. The major concern of respondents was the potential effect of increased off-road vehicle use on the Orocopia Mountains Wilderness Study Area and on its biological resources. The bighorn sheep and the desert tortoise were wildlife species mentioned several times. The unique geological formations within the closure were another resource in need of protection, according to one correspondent. The three respondents who favored the amendment provided no rationale.

Questions on the locations of routes of travel within the closure indicated that more information was needed on this topic. These and other questions and comments are addressed in the following section. 
AMENDMENT THREE - MODIFY BOUNDARY OF SALINE VALLEY ACEC

This proposal was approved by all respondents who mentioned it except for three who stated that some of the land to be added to the ACEC is heavily mineralized; they feared that ACEC status would restrict mineral exploration and development of this land. Those favoring the amendment supported BLi's effort to protect marshlands and streamside habitat, as well as cultural and historical sites.

\section{AMENOMENT FOURT- REMOVE BURROS FROM KRAMER AREA}

Two-thirds of the 46 respondents commented on this amendment. All of them favored removal of federal burros from the Kramer Hills. Reasons given were protection of wildlife habitat (desert tortoise and Mojave ground squirrel), reduction of soil erosion, protection of native vegetation and cultural resources, and removal of a nuisance to U.S. Air Force Operations at Edwards Air Force Base.

\section{AMENOMENT FIVE - MOVE UTILITY CORRIDOR BB TO THE NORTH OF INTERSTATE L5}

Again, two-thirds of all the respondents mentioned this proposal. A large majority opposed the amendment. Most listed reasons for not wanting the corridor extended to the north; a few insisted that it not pass through the East Mojave National Scenic Area on either the north or tine south side of the interstate. The most common concerns were the Halloran Wash ACEC and tine two Wilderness Study Area (Nos. 22.8 and 242) north of I-15, which the writers feared inight be damaged by the construction and naintenance of utility lines and other facilities. Several respondents noted that the Shadow Valley tortoise haisitat would be endangered by extension of the corridor to the north. A utility company opposed the ainendment because the usable width of the realigned curridor would be only about one-quarter mile as it passes soutin of the WSAs. They wanted to maintain a 3-mile-wide usable corridor. A governmental agency stated that the proposed corridor would infringe on numerous mines, claims, and mineral deposits and that stility facilities would affect tine potential for open-pit mine development and mine waste disposal in the area. These concerns are addressed in the following section.

AMENDMENT SIX - CARRIZO GORGE WILUERNESS STUDY AREA

With one exception, all commenters on this proposal endorsed the Bureau's decision to make tiis sinall change in the Carrizo Gorge Wilderness Study area. The lone dissenter reconnended keeping the short routs open for tine benefit of people who are unable to walk the siort distance to the overlook.

\section{AINENDMENTS NOT CONSIDERED}

Several respondents questioned the decision to not consider amendment proposal 85- -3 , which asked for a change in veinicle access in the Randsburg area from "limited" to "closed." The proponent gave as rationale the recent proliferation of ORV trails near Randsburg and the resultant soil erosion and potential endangerment of biological resources. The Bureau's reasons for dropping the proposal was that the Randsburg-Rand Mountain area has been a subject of the earlier studies which determined that the present multiole use classification and venicle access designation were appropriate for the 
resources and activities in the area. Opponents of this point of view noted the declining populations of the desert tortoise in areas of ORV use and stated that the Bureau is not taking action to protect this species. These comments are addressed in the following section.

Another proposal which a member of the public wished the Bureau to pursue was 86-P-12, which requested a change in the wilderness recommendation for the Coyote Mountains from non-suitable to suitable. This action would provide long-term protection for recently located paleontological and archeological resources. The respondent wanted proof that the Bureau had the methods and the necessary financing to provide adequate protection for these resources under the present non-suitable status.

\section{SPECIFIC COMMENTS AND RESPONSES}

The following table presents specific comments made by individuals, organizations, and governmental agencies during the 60-day public review period and the responses to those comments. The comments pose specific questions regarding the environmental assessment. They are direct exerpts from the original letters rather than summaries. The table lists the commenter, the comment, and the BLM response. Whenever other respondents raised the same question, they are listed beneath the first commenter. 


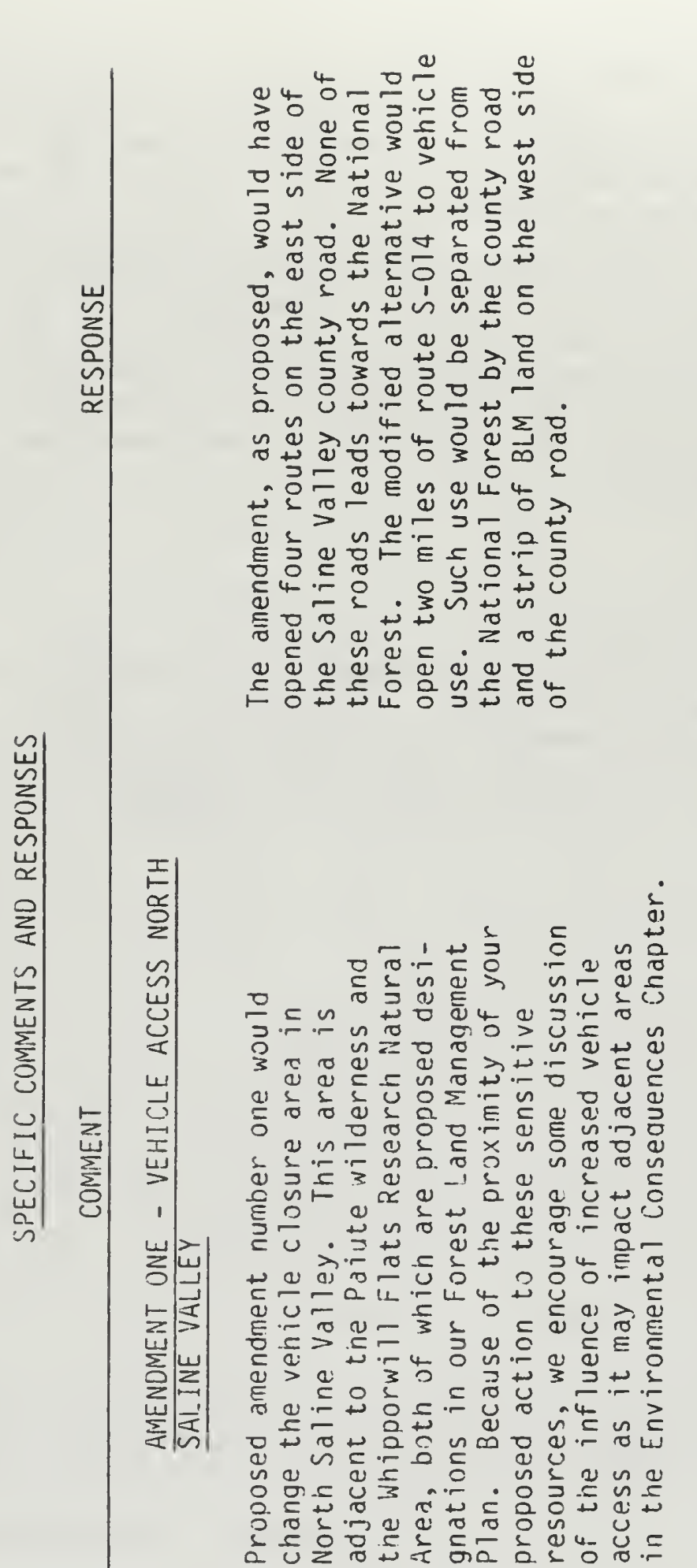

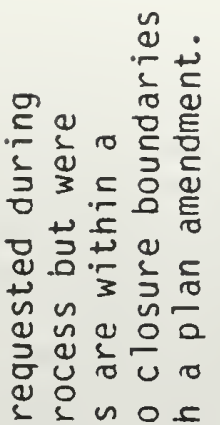

造出向

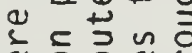

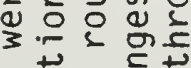

的范

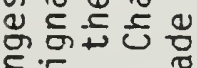

的它

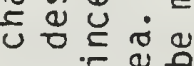

ه ه

ㅇํㅇㄷํ융

롤⿺ㄷํำ

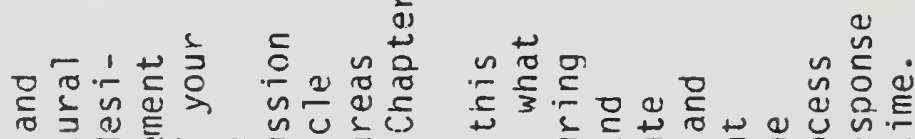

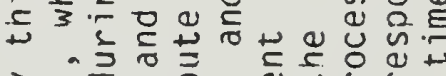
>ेंगे

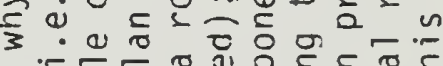
등 ฉ 은

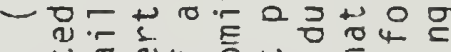

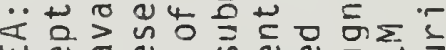

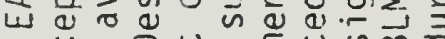
— Uू ๘ ᄃ ᄃ 4 ब aㄷํ유

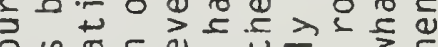

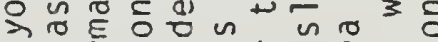

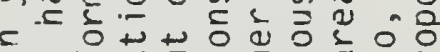

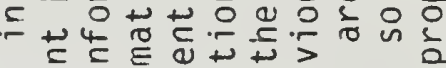
ᄃ .

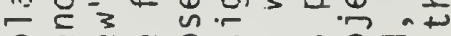

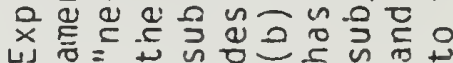
a
$.0 \%$
난

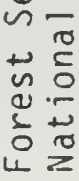
i่

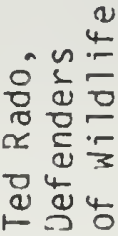

点 

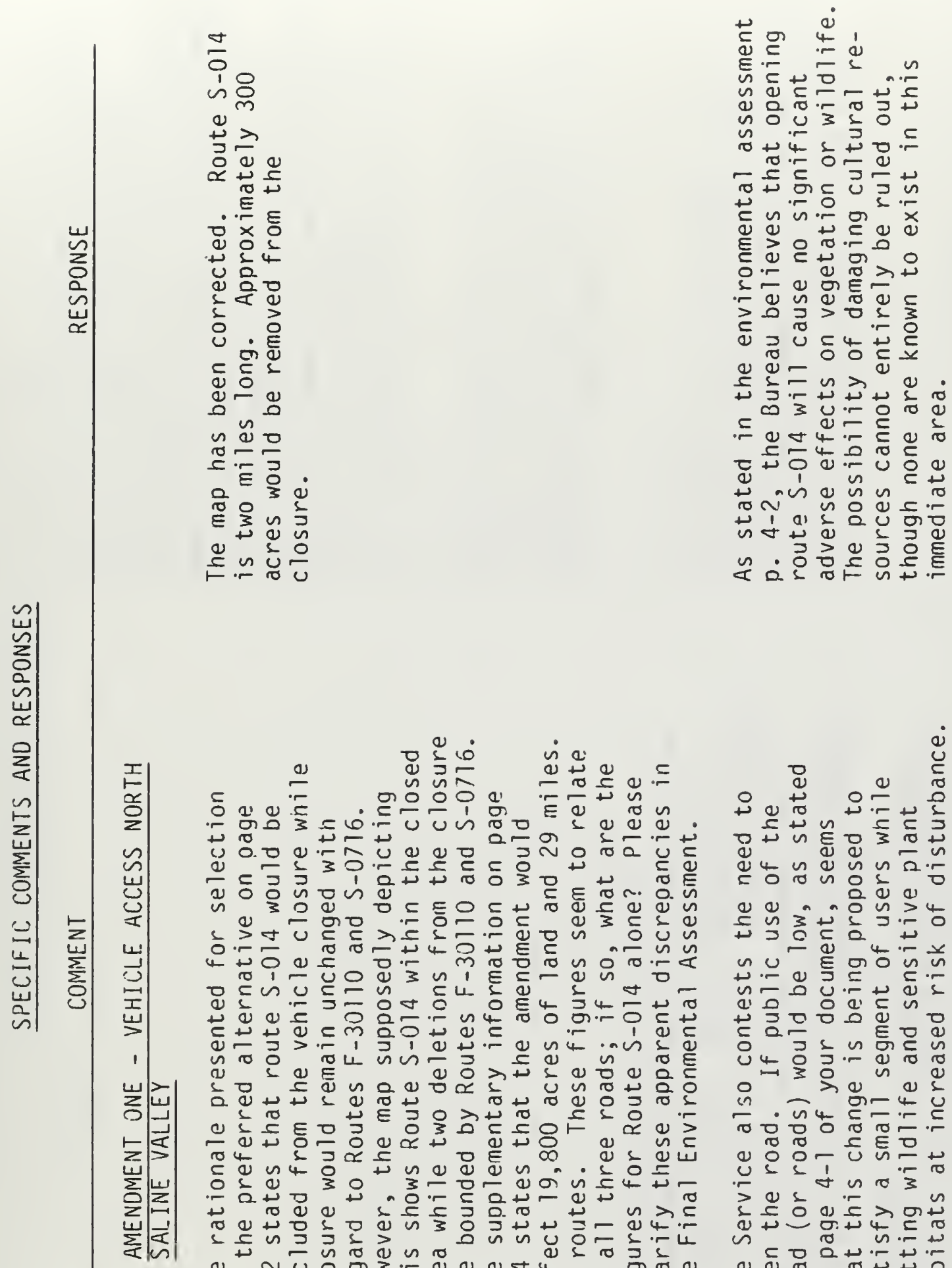

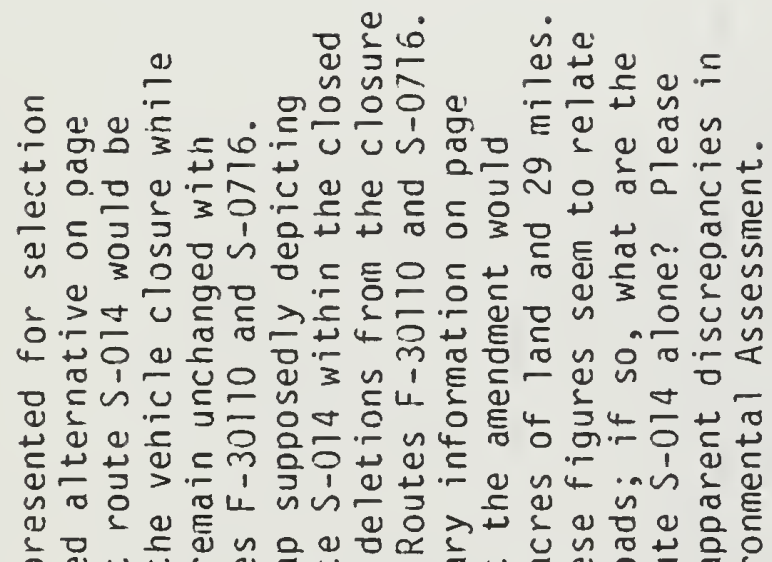

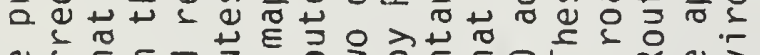

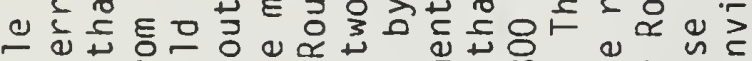

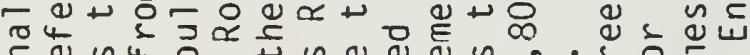
รูथ थै

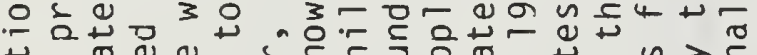
㟧

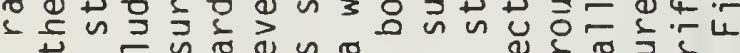

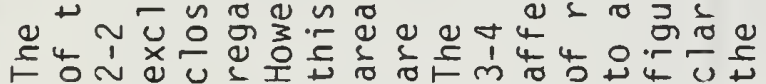

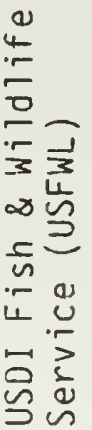

¿்

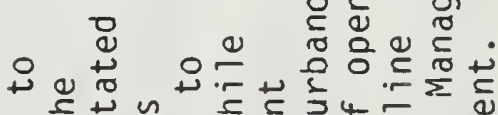

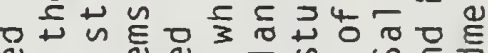

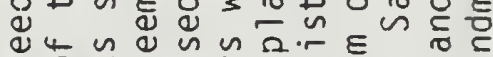

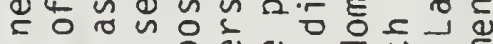
ब थ

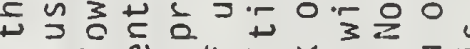
n

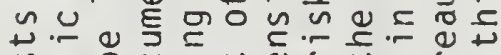
«下

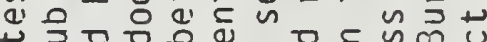

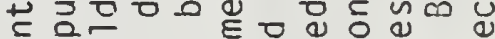
띤 n U4 -

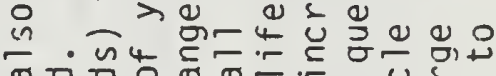
历

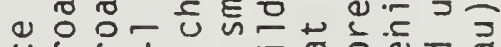

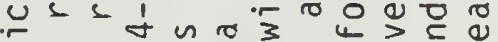
$>0$ व

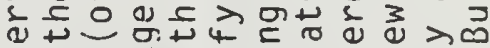
心

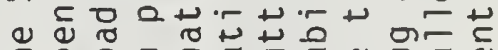

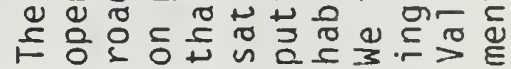

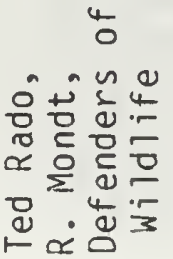




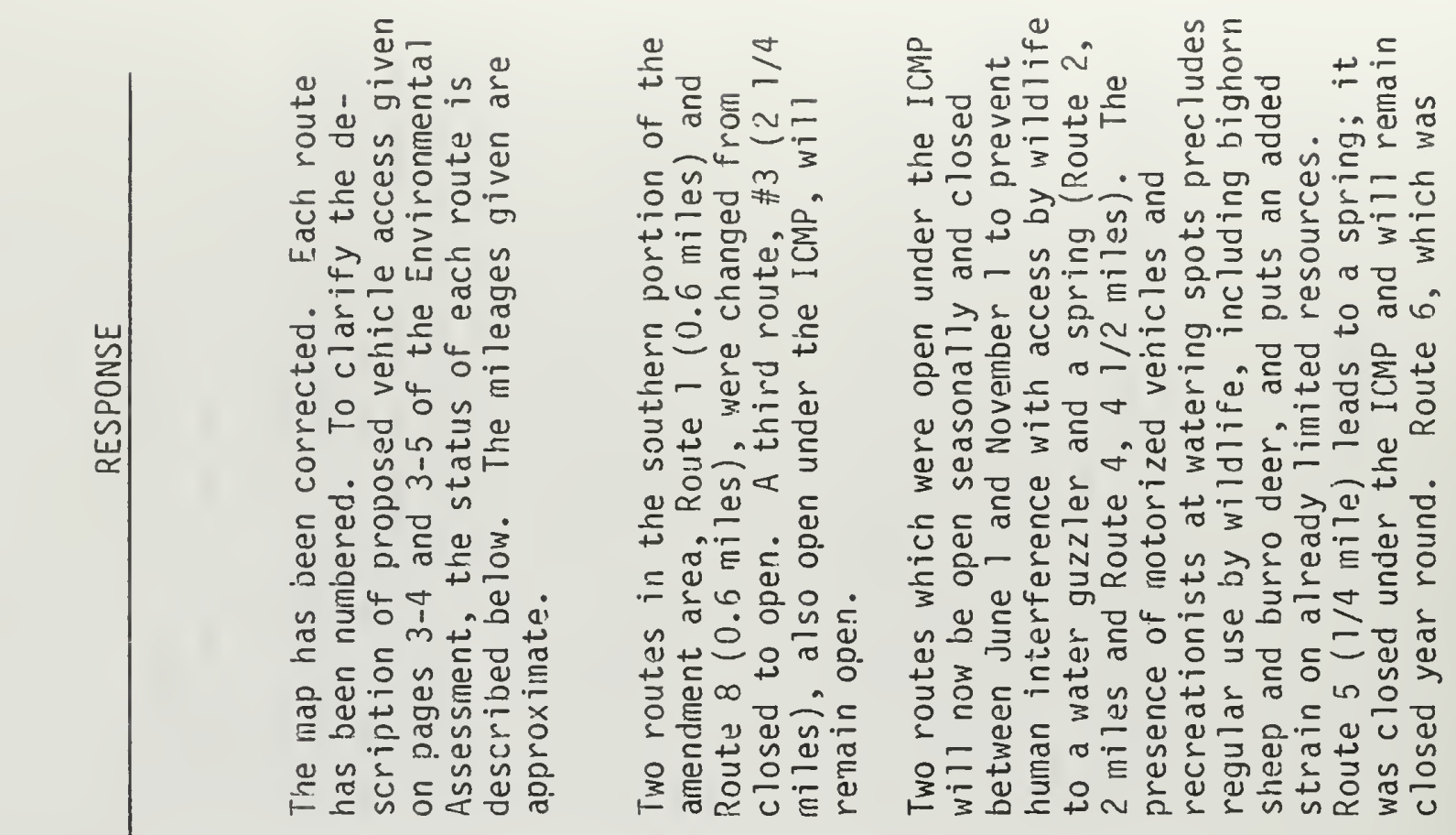

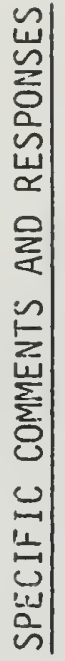

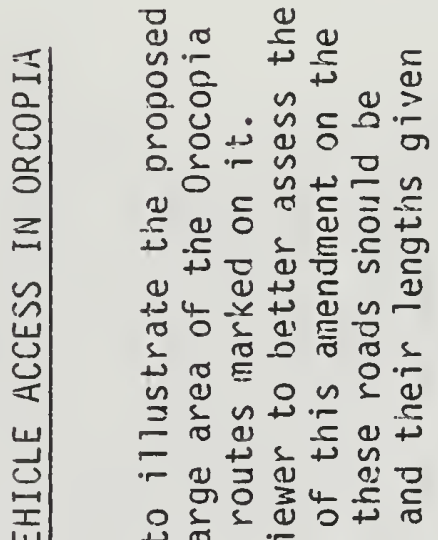

पृّ

1

인) $\quad$ ग

F $\quad$ 응 $3+40 \div$

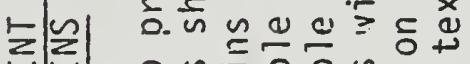

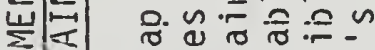

क व

$E$ पृत्र

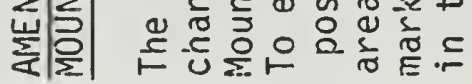

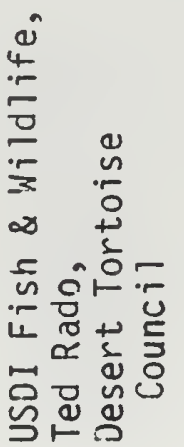




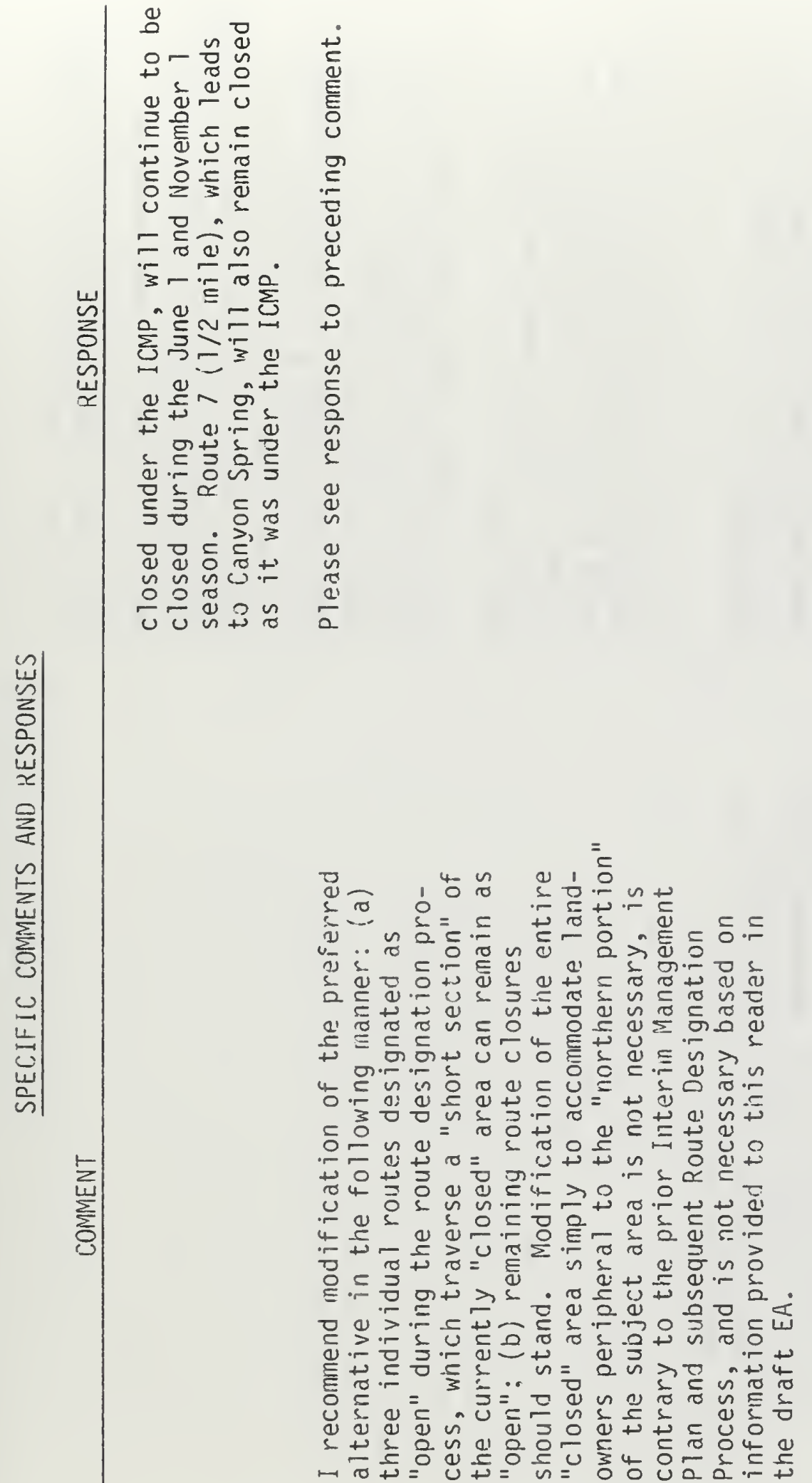

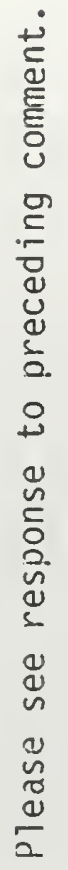

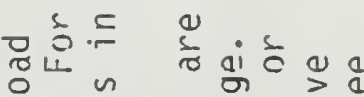

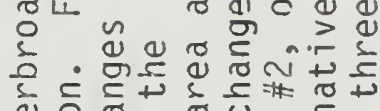

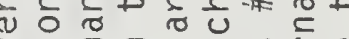

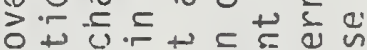
r

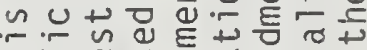
N.下 \# 䓃잉 巳

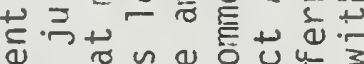

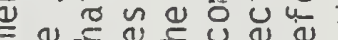

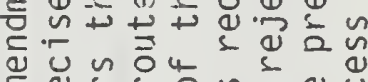

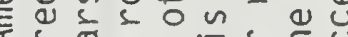

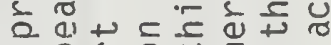

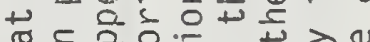
듬다

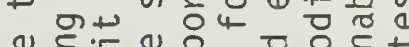
य.

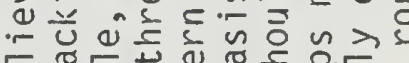

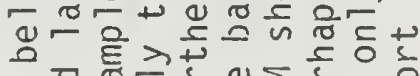

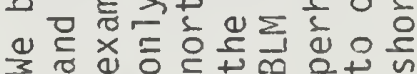

궁

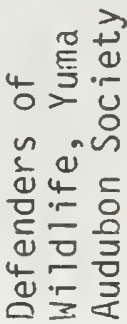




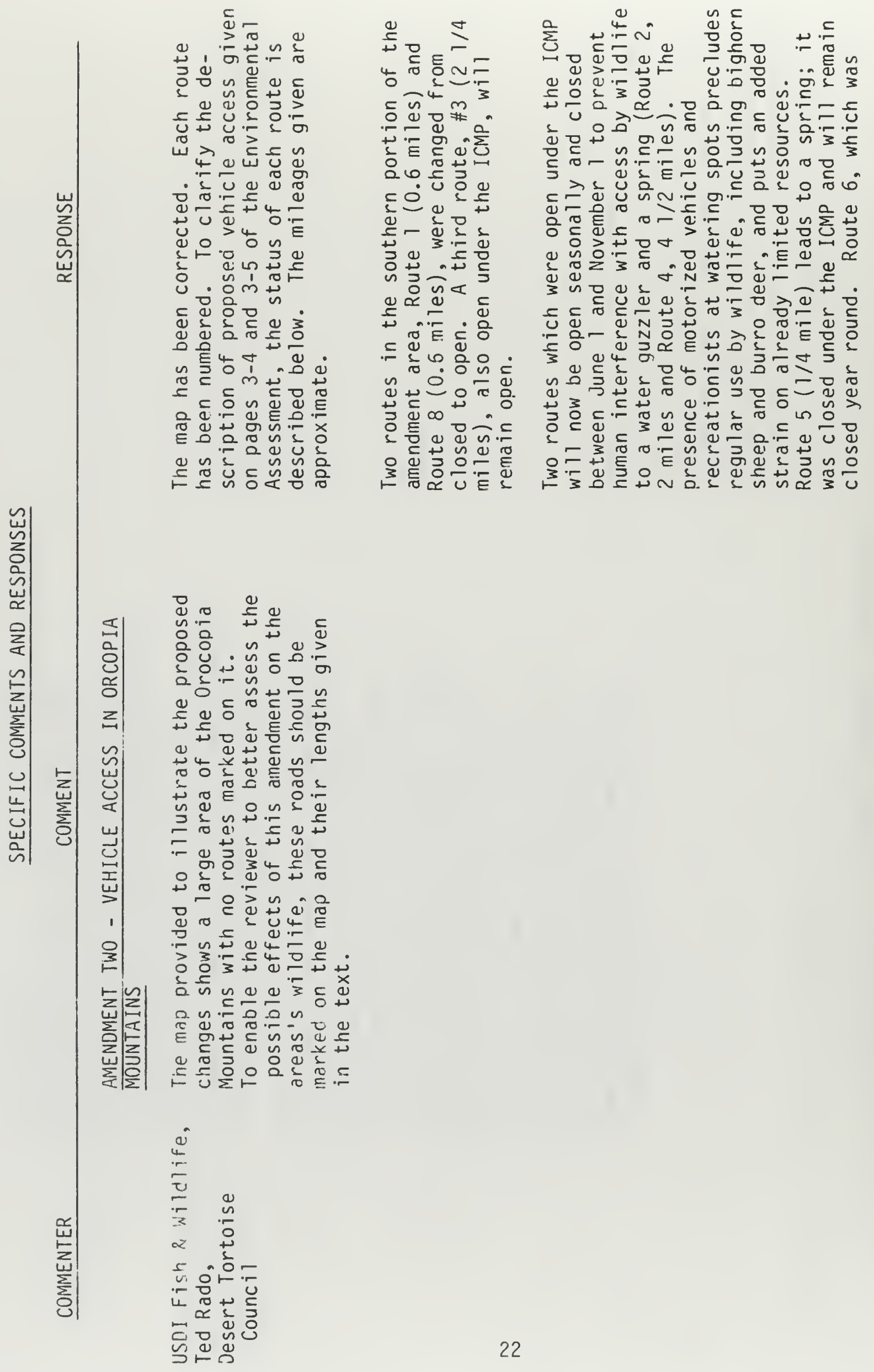




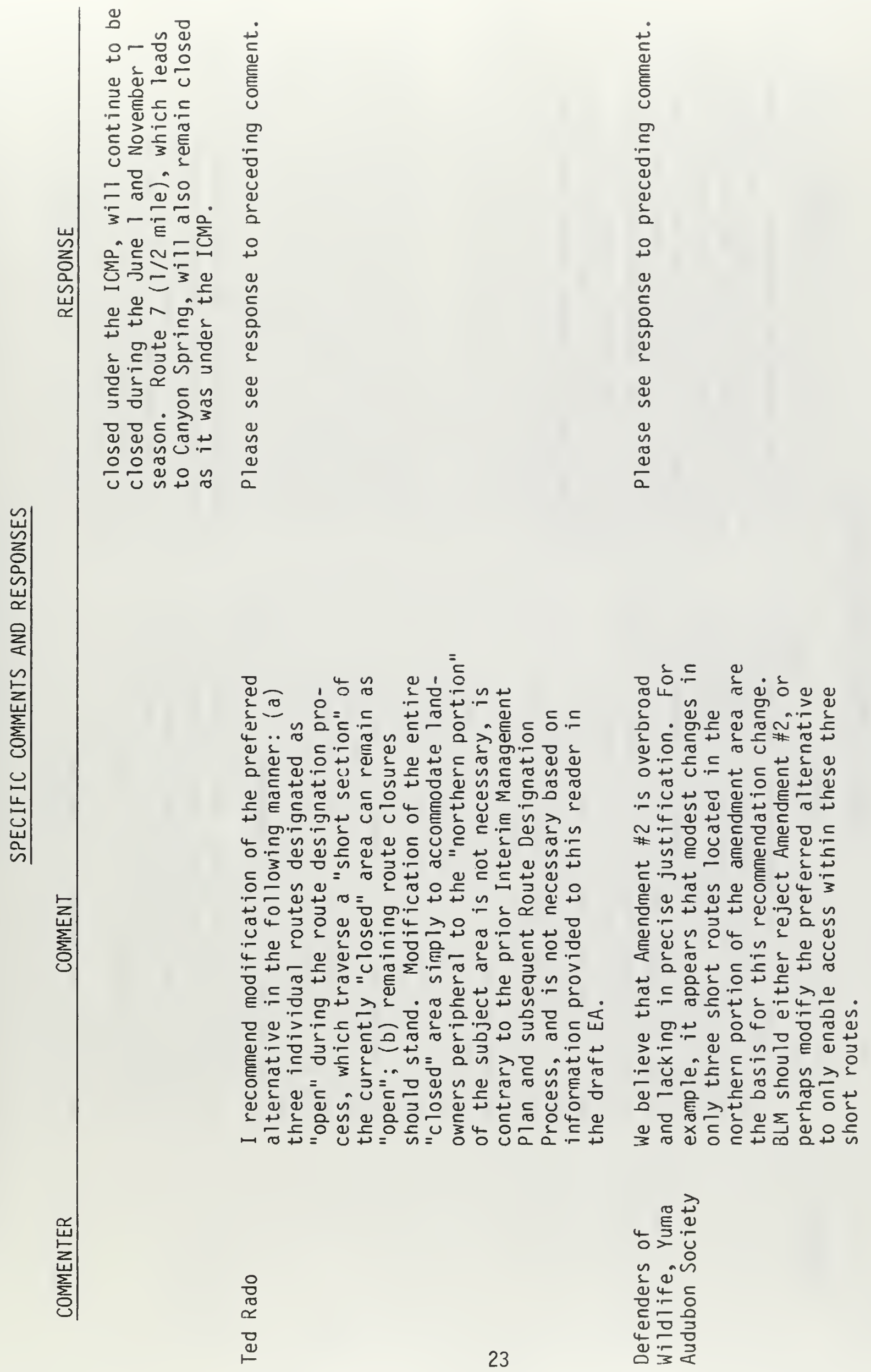




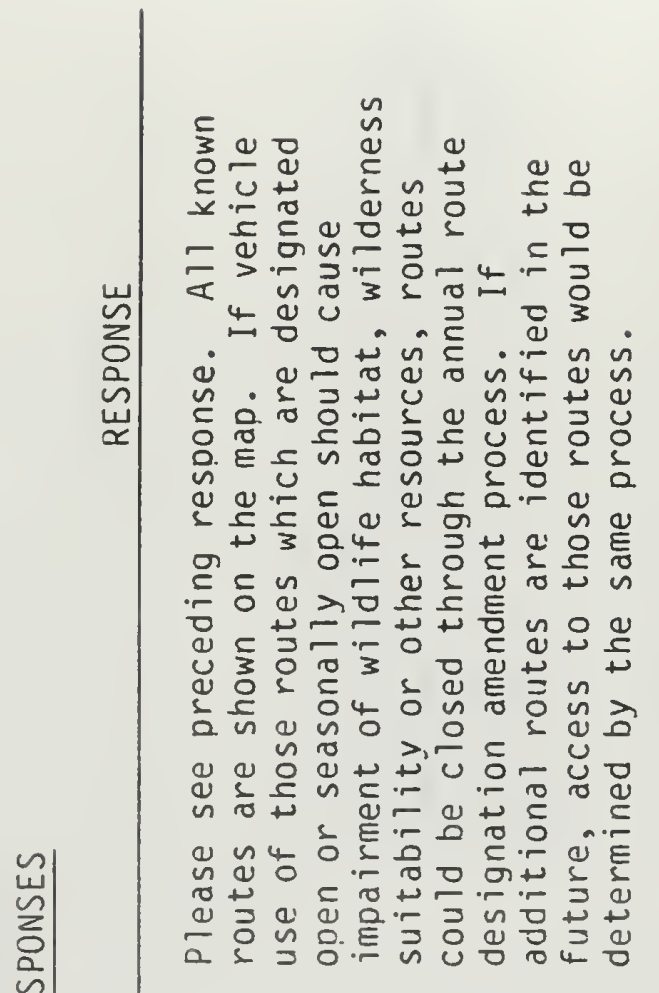

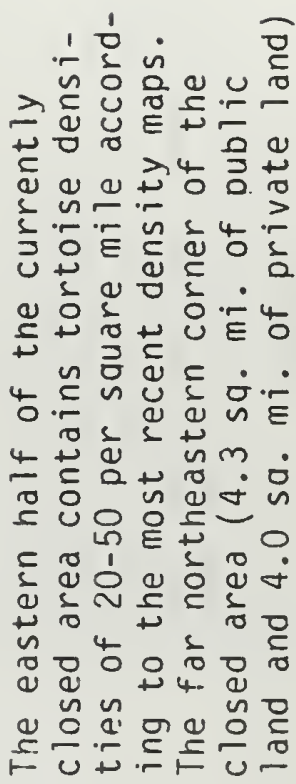

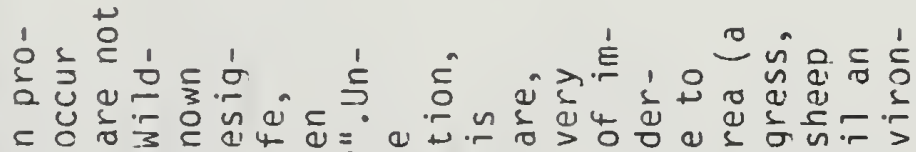
佂二

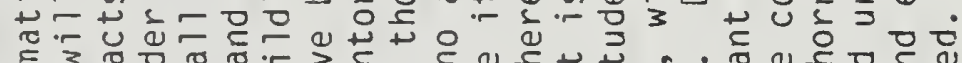
E 3 융

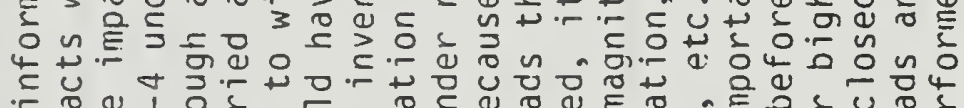

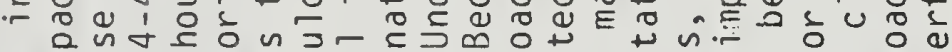
ᄃ 윹

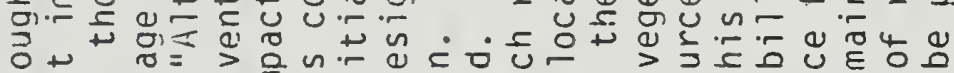
은

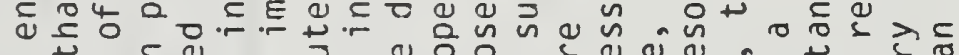
世む 응표

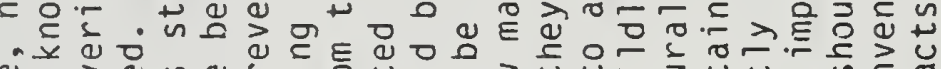
i

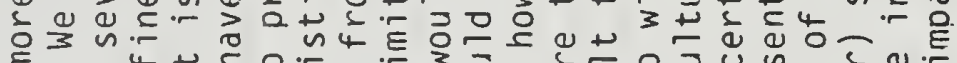
ह 3 थ 峁

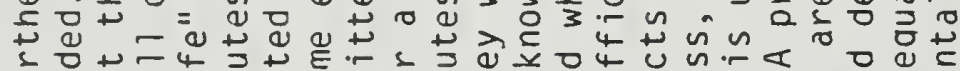

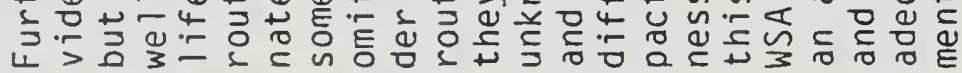

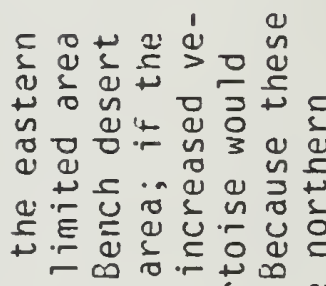

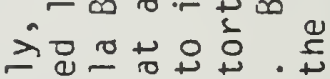
ॠ

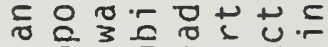

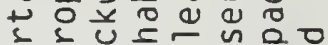
ธิ่ 足 3 孚 है

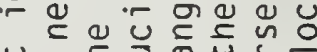
แै 올 $=$ Uं

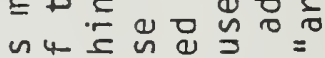

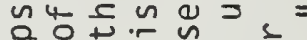

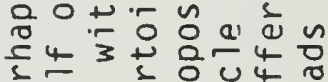

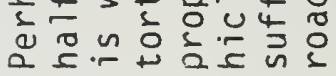




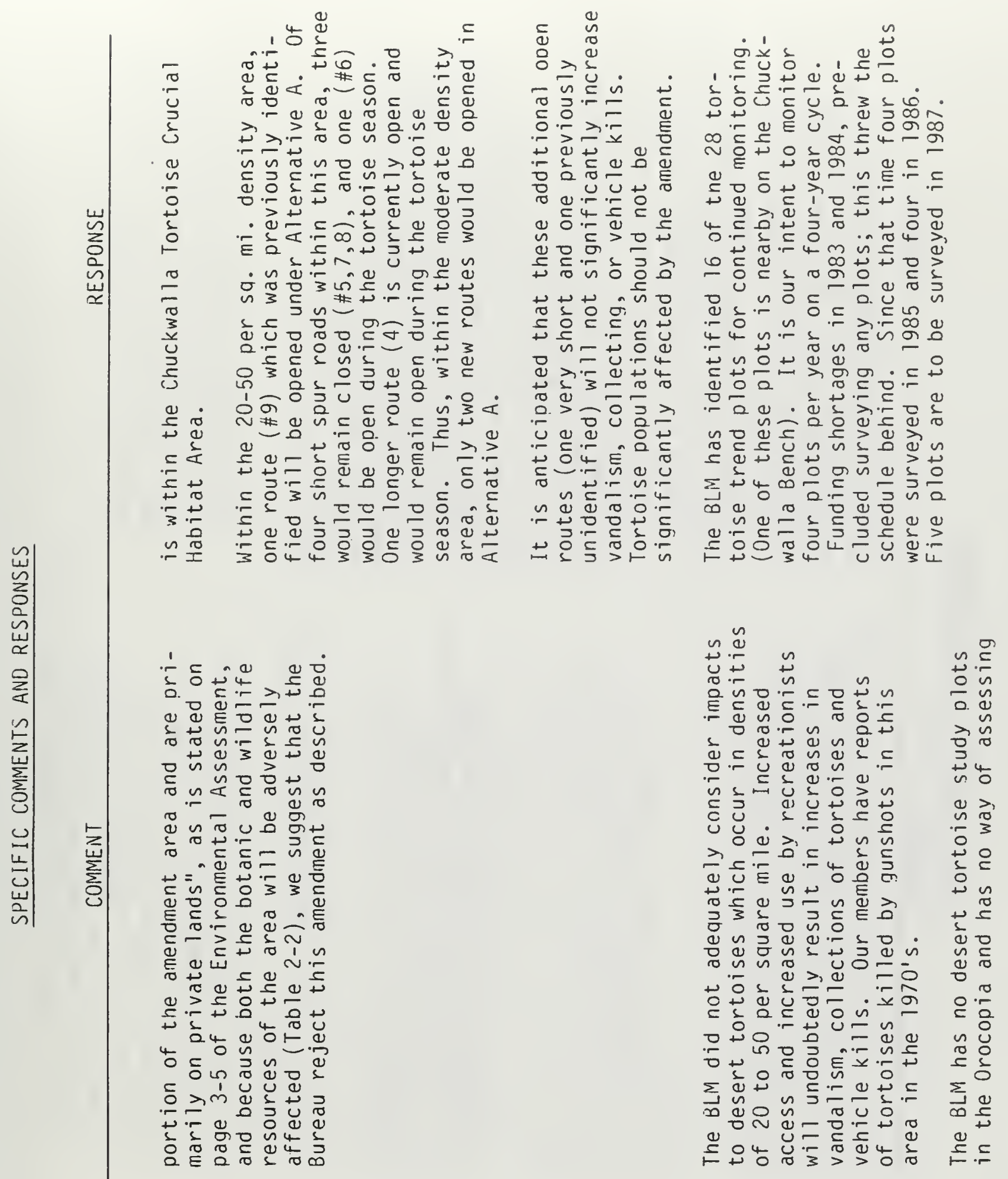




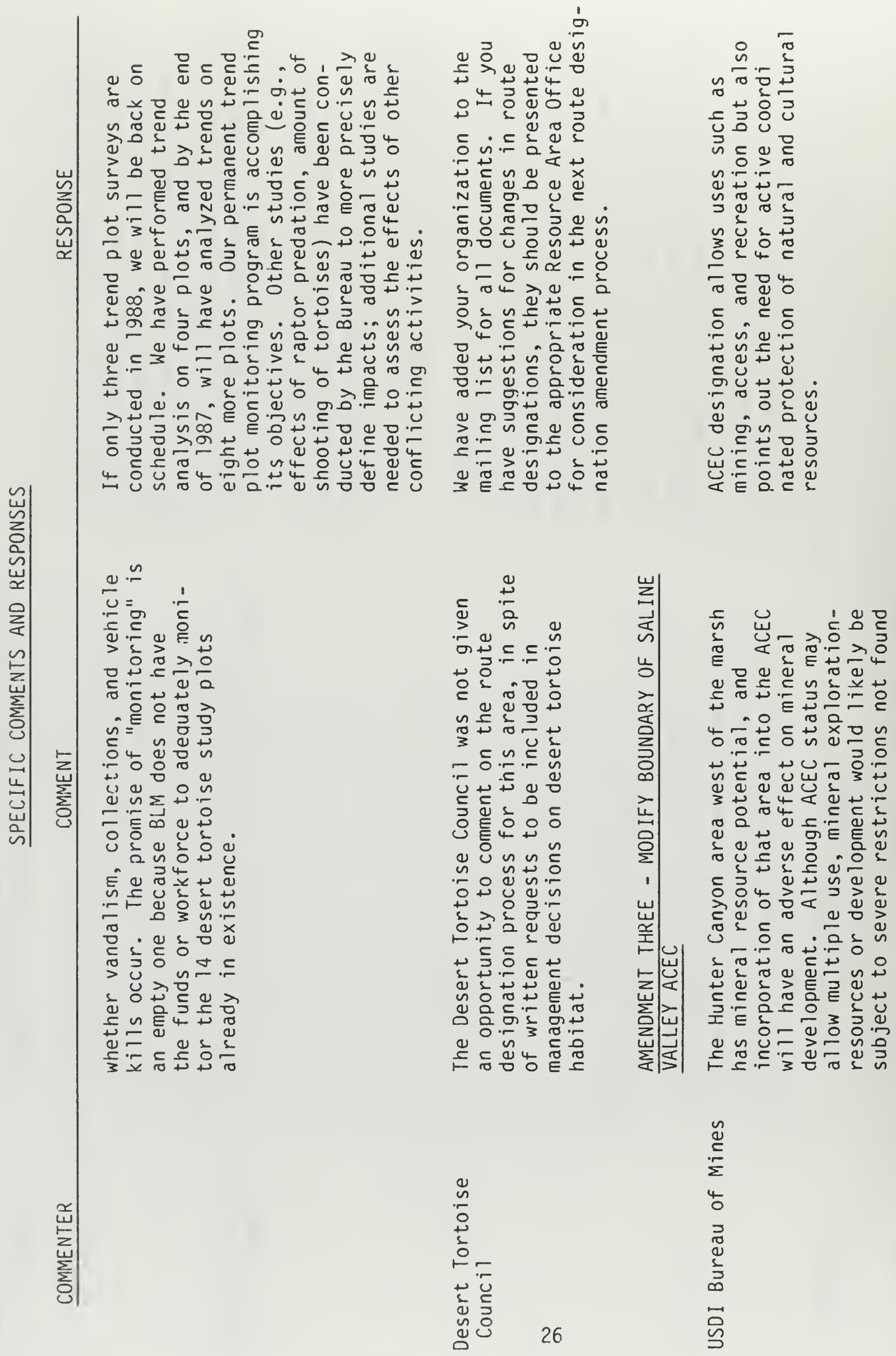




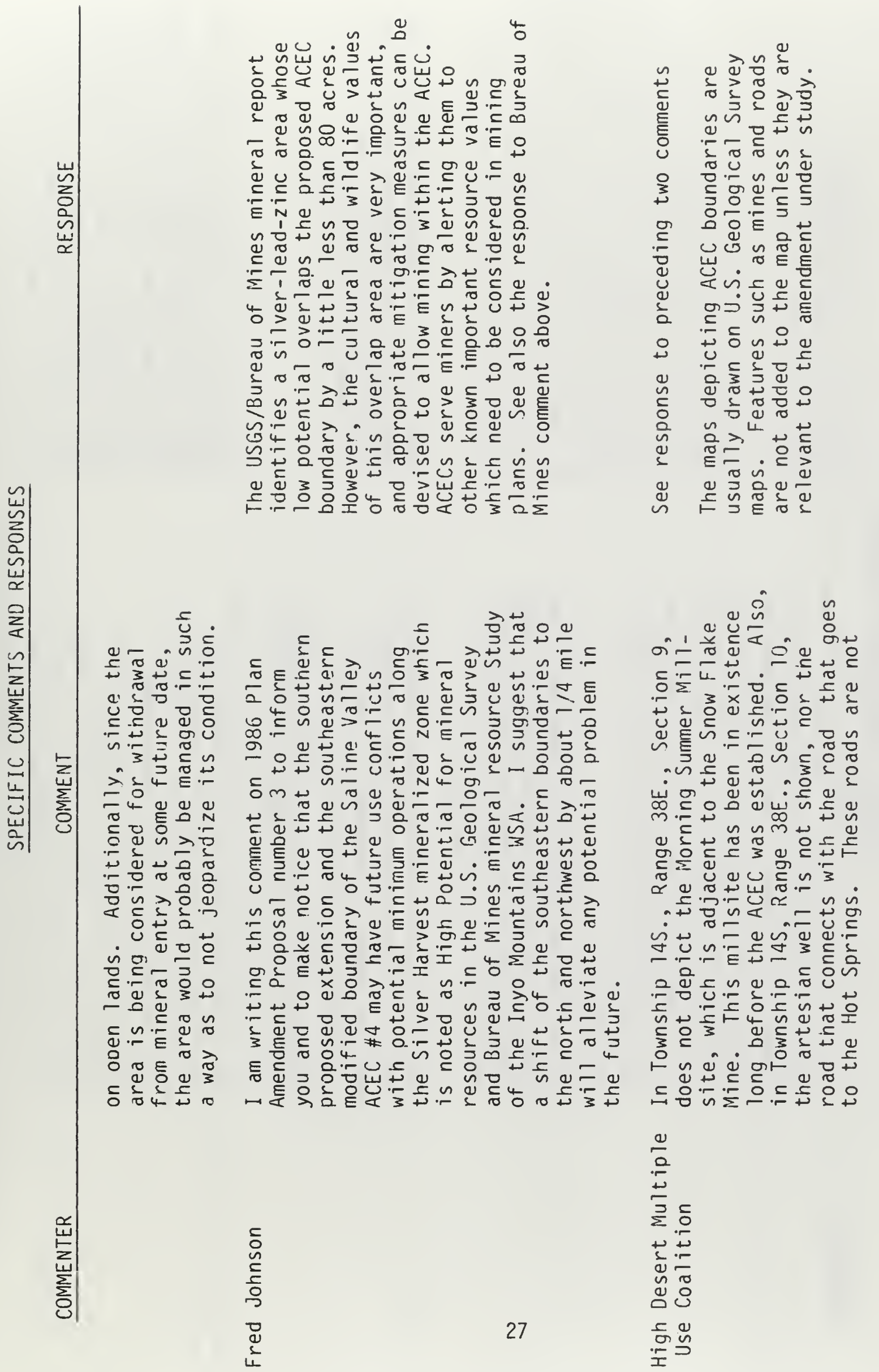




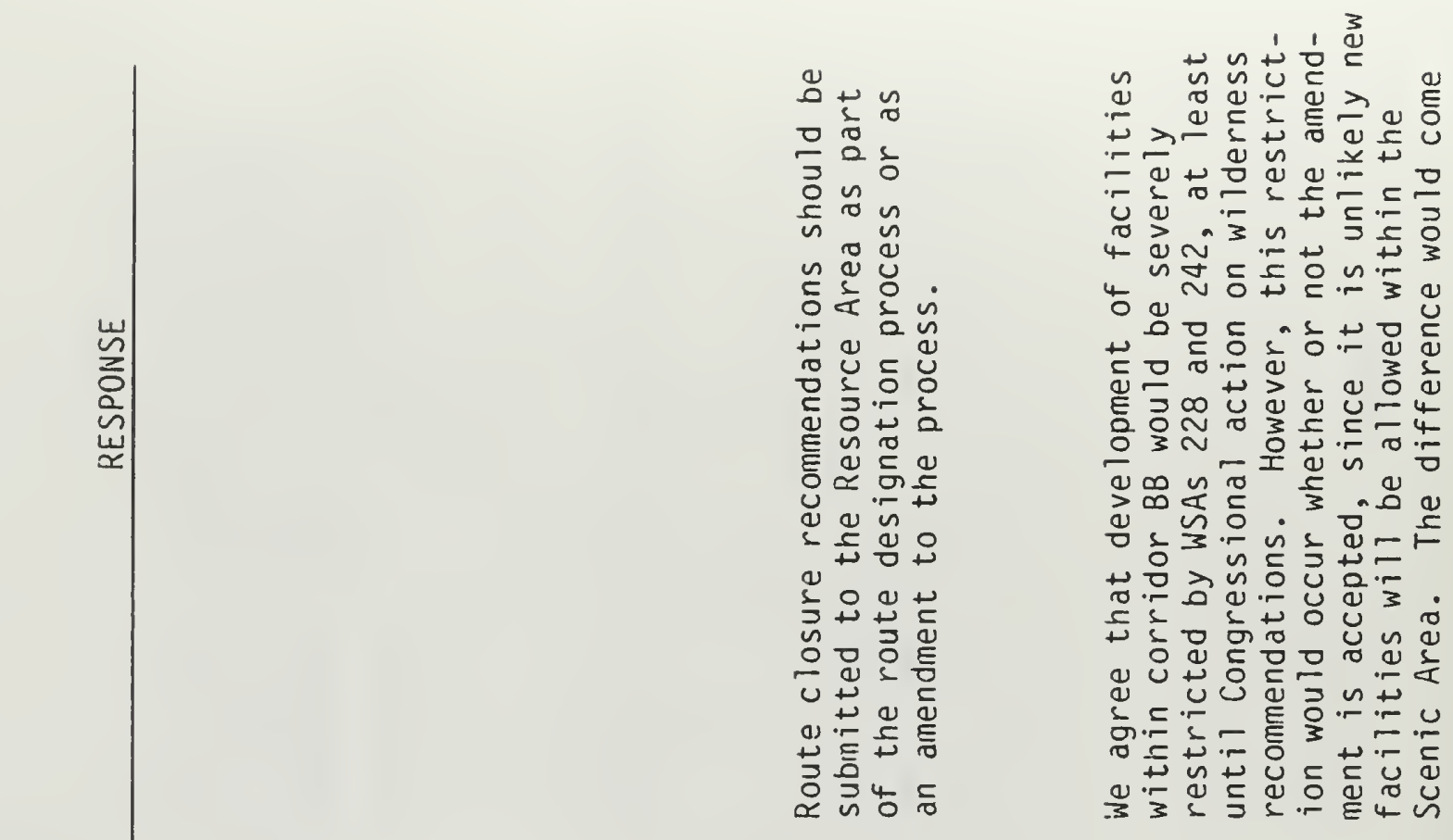

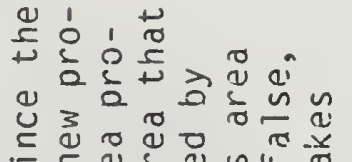

믇 $\frac{1}{2}$ 잉

을 농

乞 $\simeq \frac{1}{4}$

$\infty$

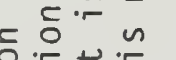

जब

نั

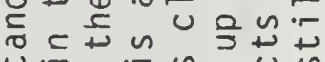

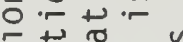

艺范岳

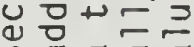

ज

$=$ प $\frac{1}{2}>$

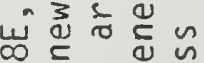

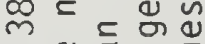

வ

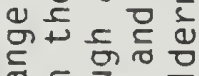

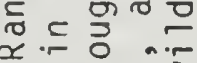

ये

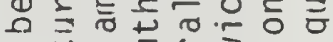

व

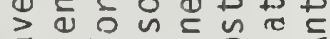

$\left\{: \frac{\pi}{3}\right.$

वư

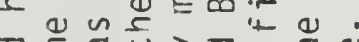

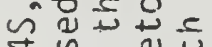

$\therefore$ 的

응 원

은윰ㄴ

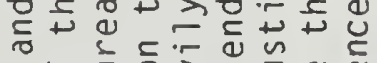
4 的印

हब

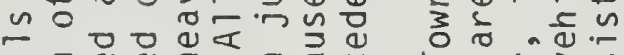

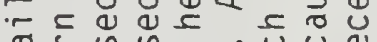

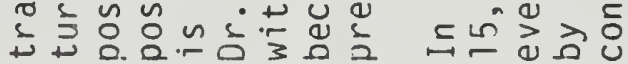
응

$\leftarrow$ 凹 ᄃ

- ه广

U

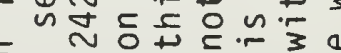

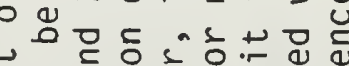
은헤

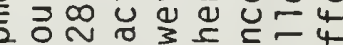
3N 옹 n

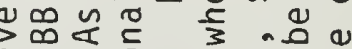
ปร

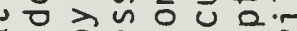

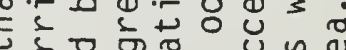

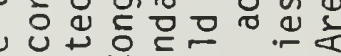
u u d 든 ह 을

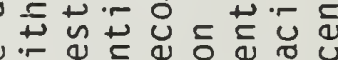
उ3s $1.0 \stackrel{E}{4} \sim$
ज 드

ธथ

○ U ज岂

in 유다

두워

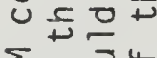

$\sum_{-1}>0$

a 8 i

\& $2 \sim \pm$

$\omega+\longleftarrow$ ᄃ

๘气 م

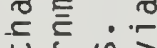

$+\frac{1}{4} \tilde{E}>$

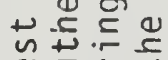

थฺ

o 응 ज $4+$

됳을

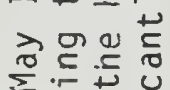

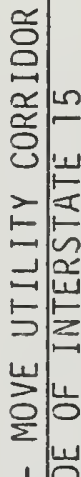

1 夜

$\stackrel{4}{2}$

凹I

文余

$\sum_{m}$

$\sum \underline{I}$

$\sum_{i=1}^{+\infty}$

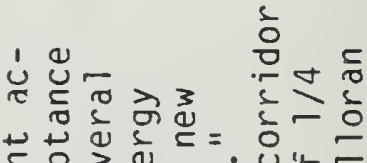

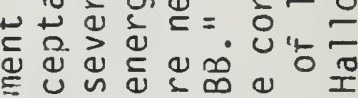
嵌 幽茴

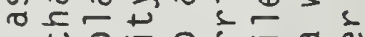
๙ 0 0.下

$+10 \Omega$ n 둑

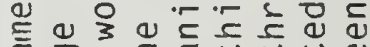
ह 을

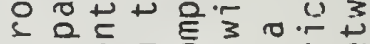

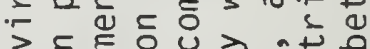
¿

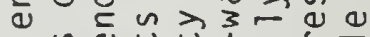

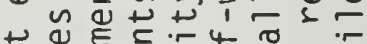
4 G ป

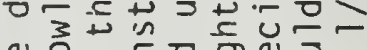

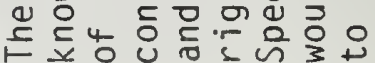

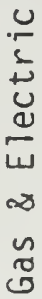

$\frac{0}{2}$

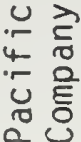




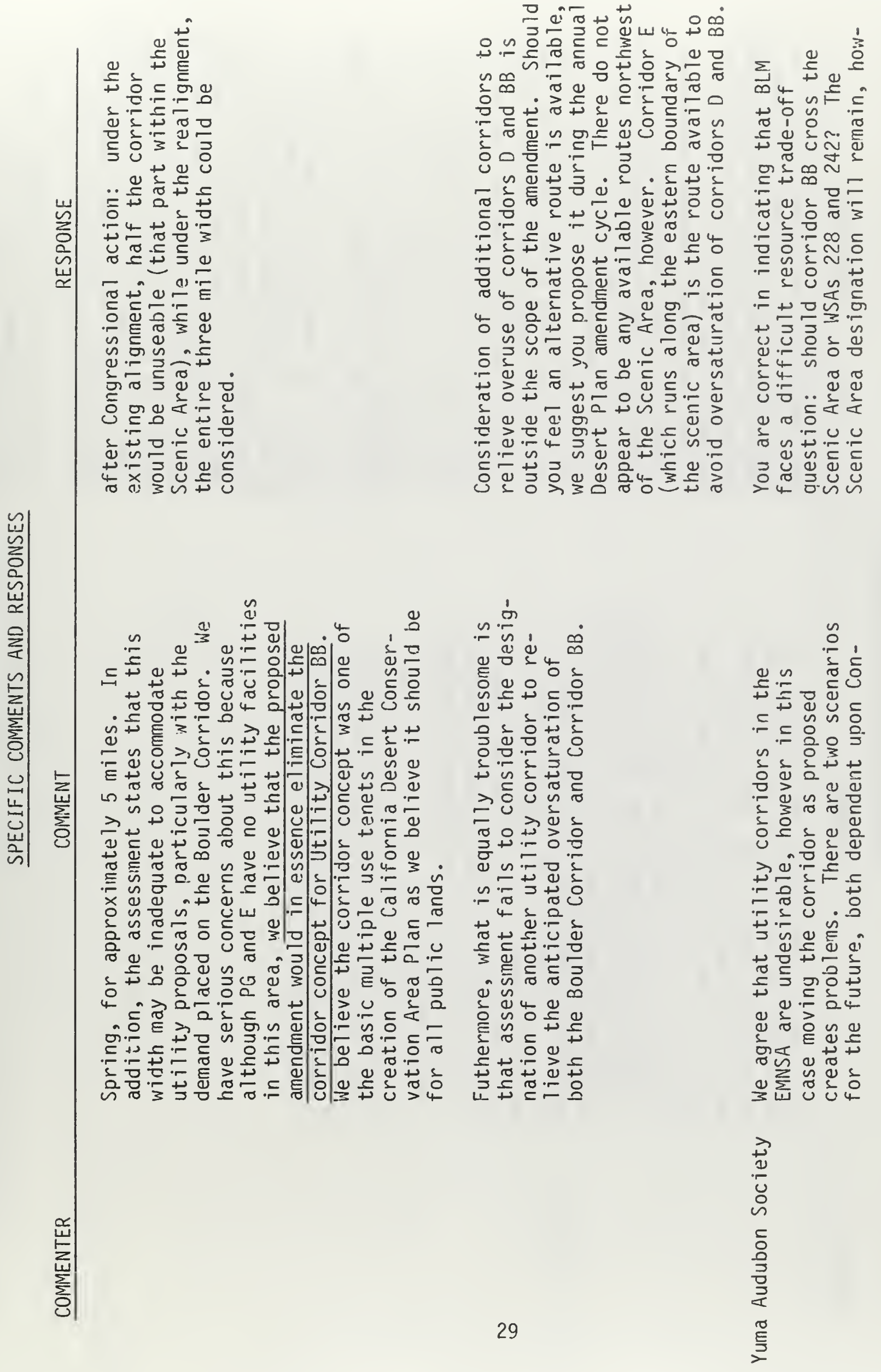




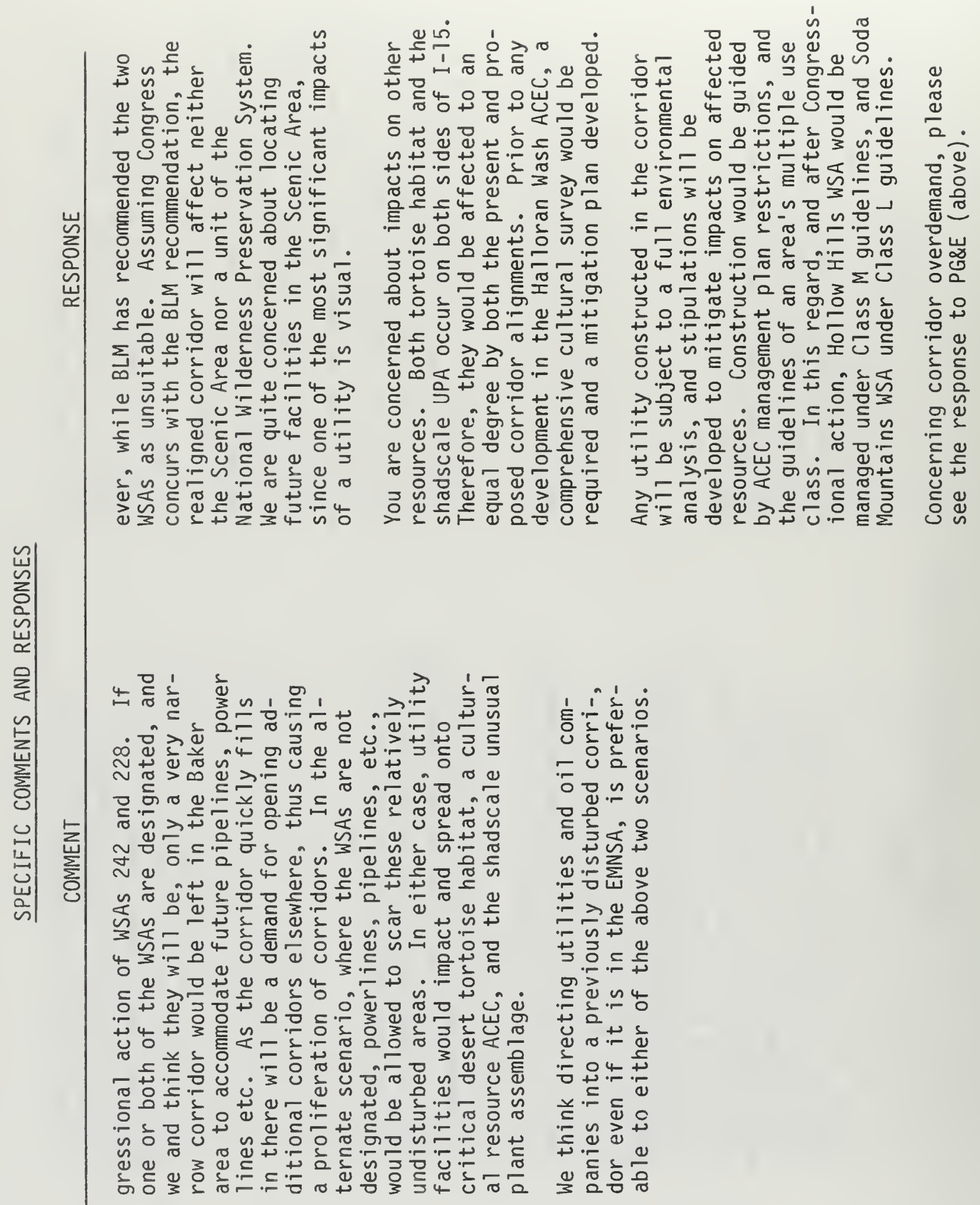




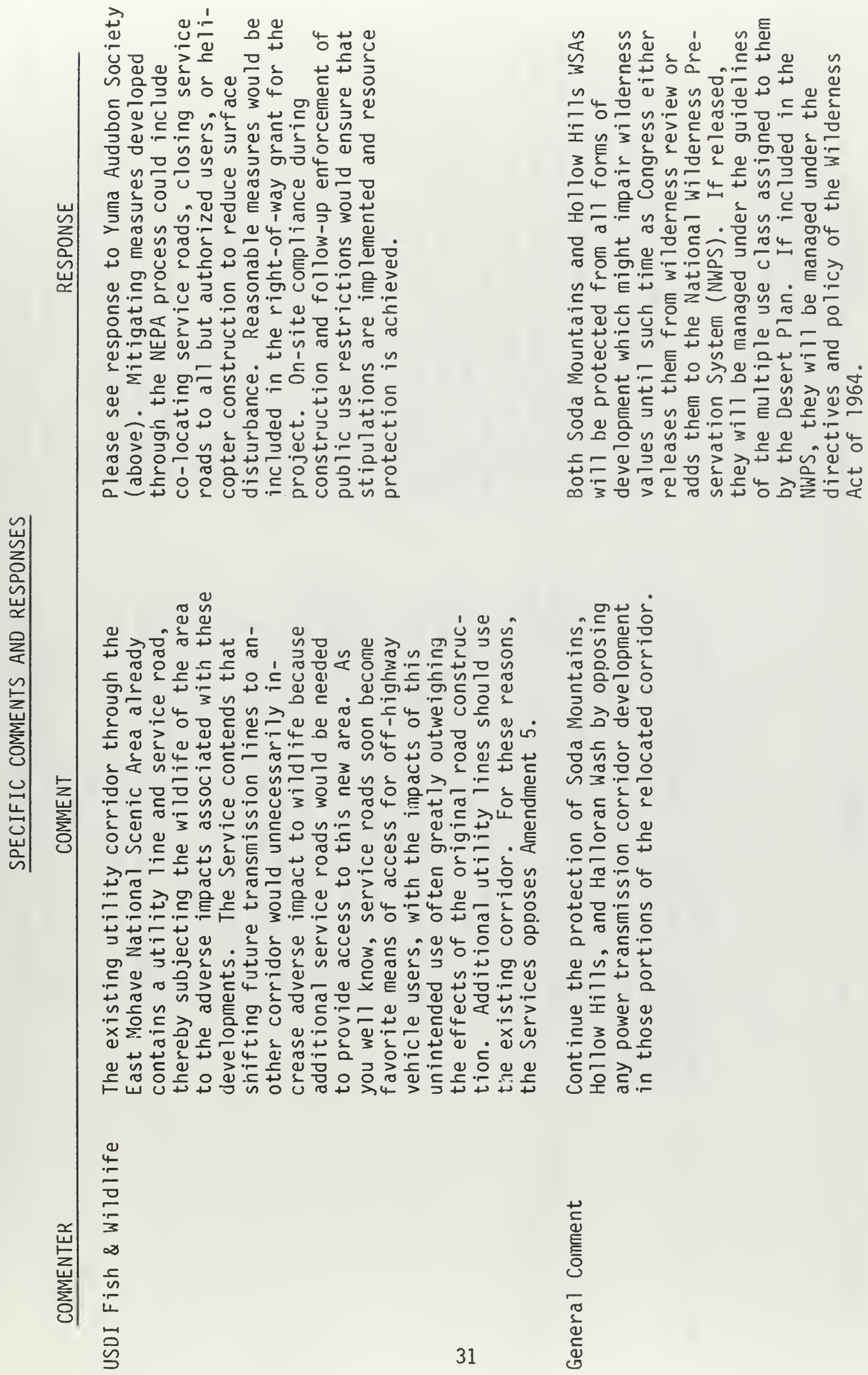




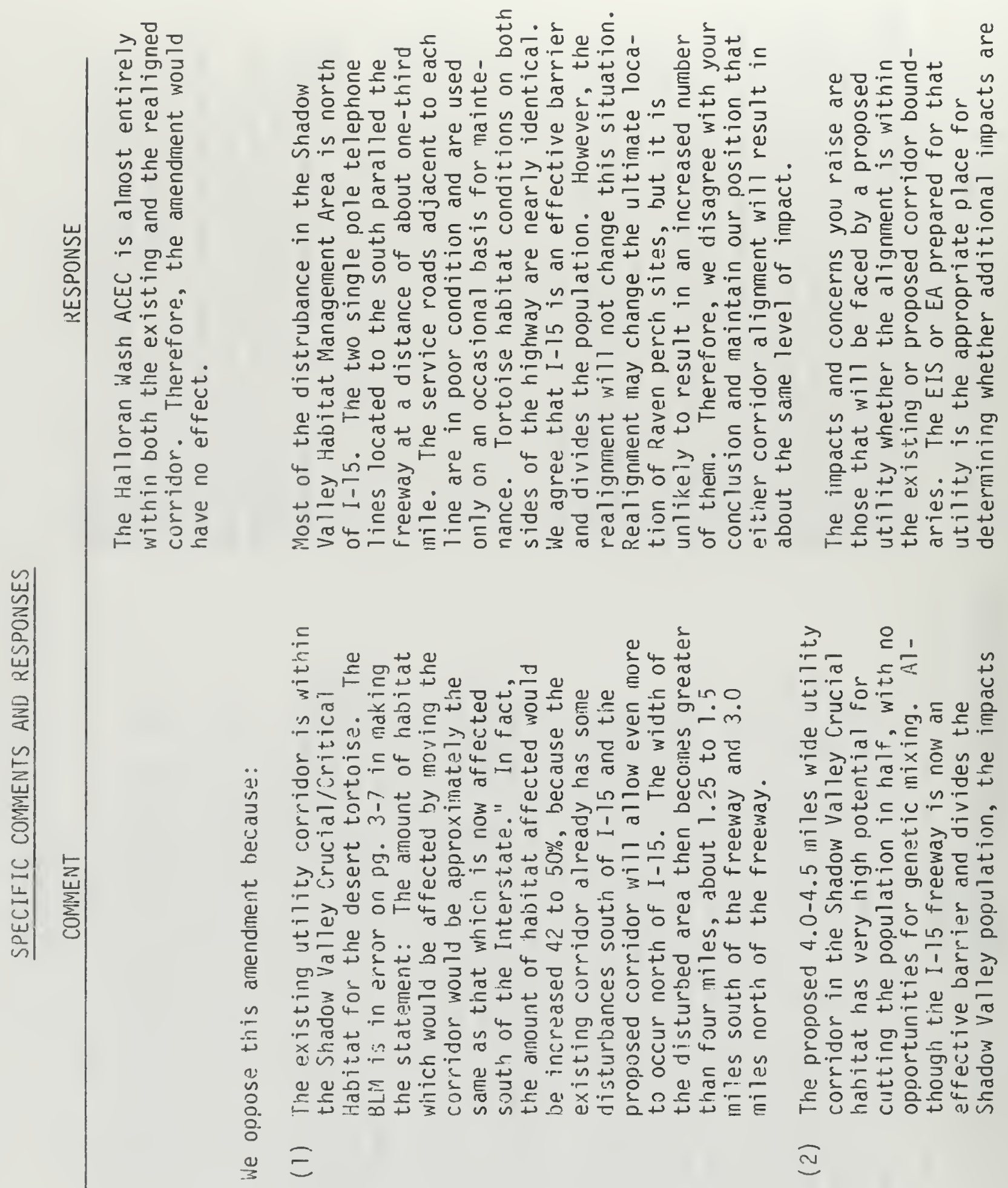




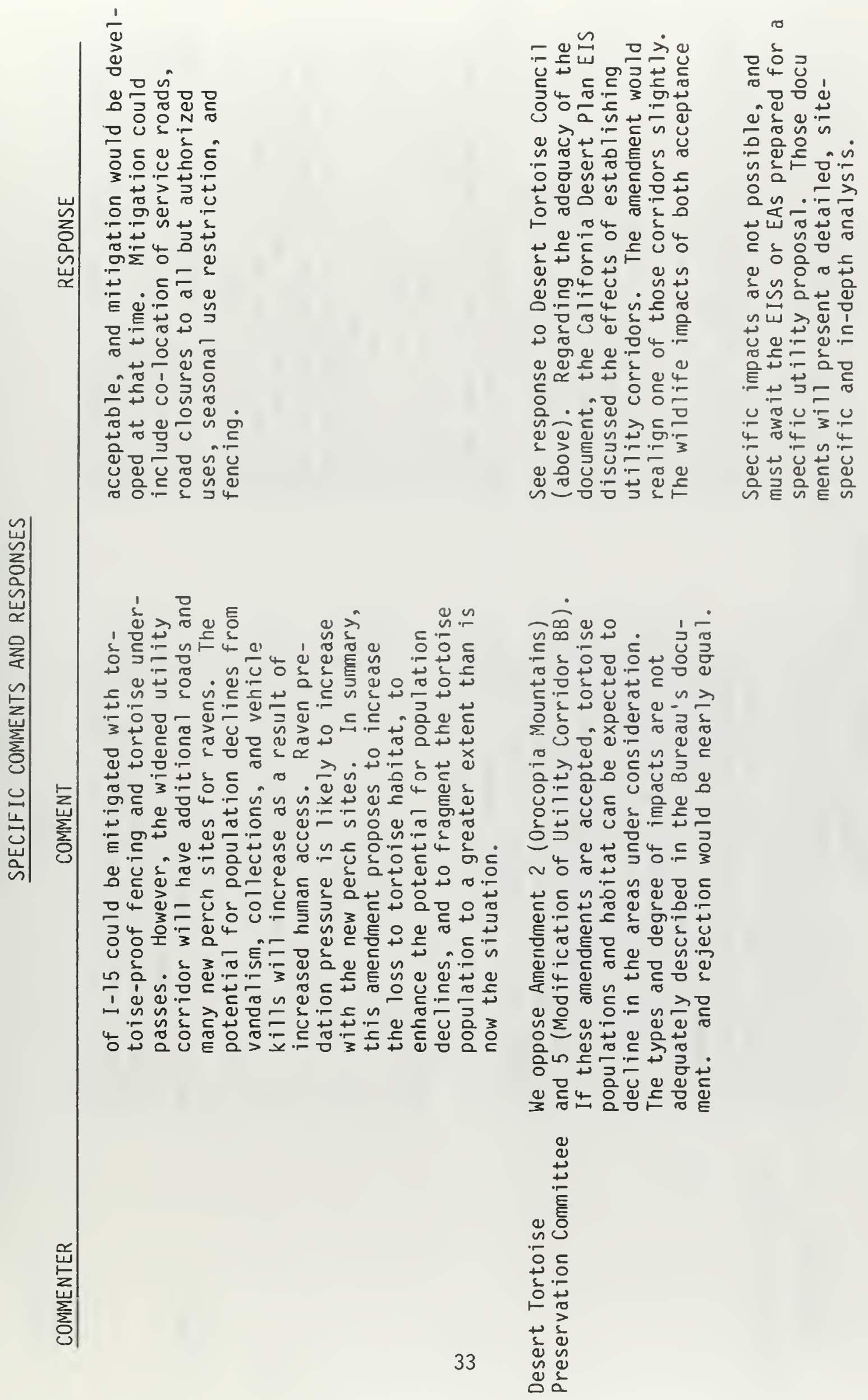




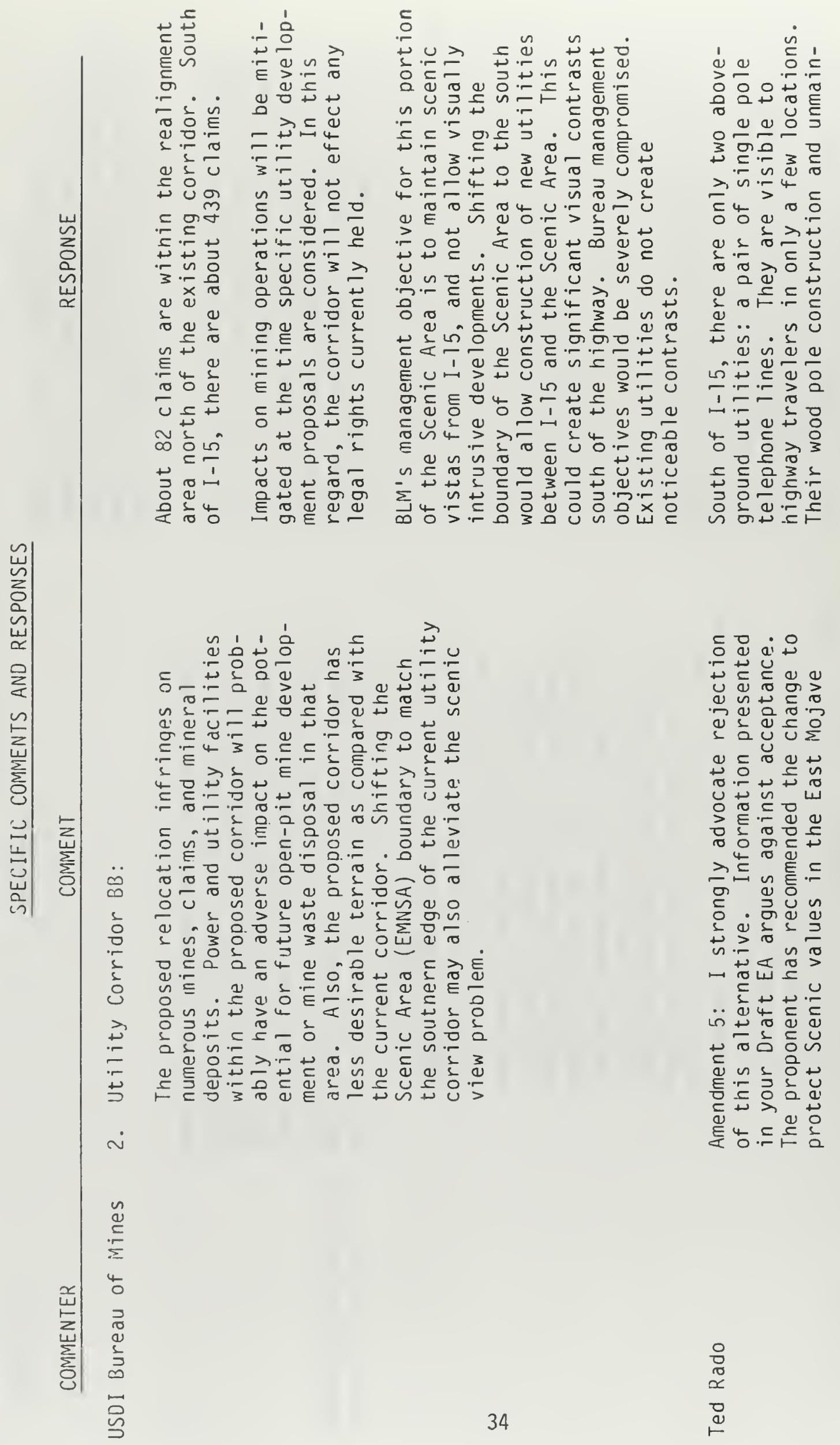


$1 \stackrel{\circ}{\circ} \cdot \frac{1}{2}$ \&

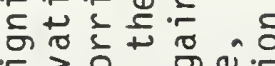

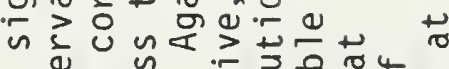

ब ڤ

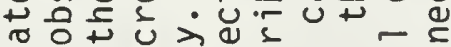
(1)

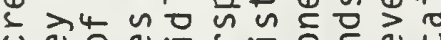

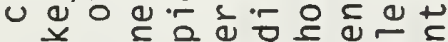

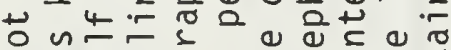
읃워

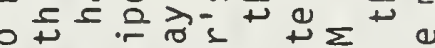
ช 틍 व

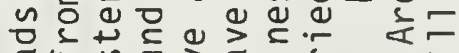
ชน

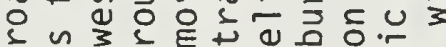

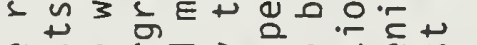

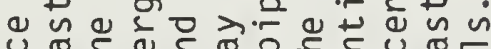
Uช

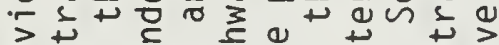

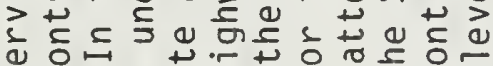

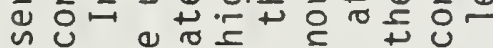

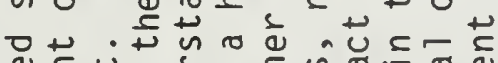
\& $\dot{1}$ है

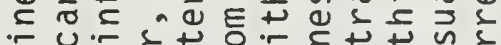

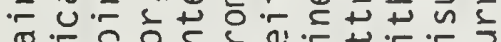

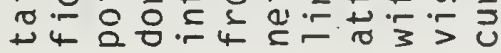

$\gtrsim \stackrel{n}{ \pm}=$ -

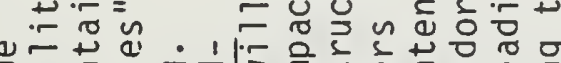

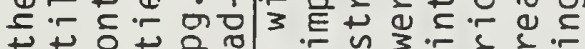

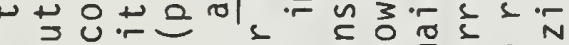
둥

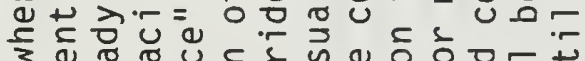

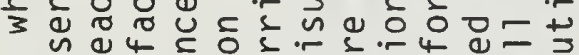
ค ณ

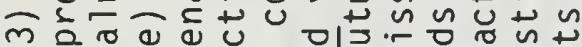

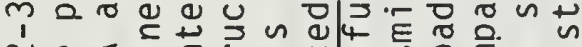

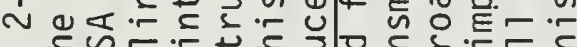

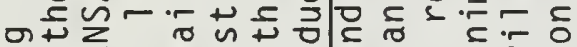
ㄴ. -

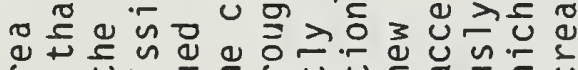

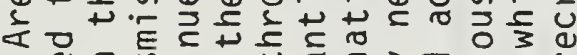

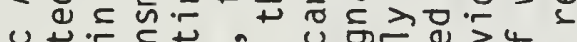

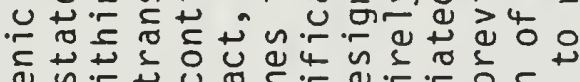

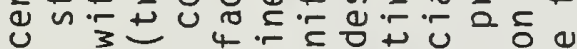

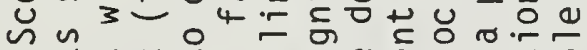
ᄃ

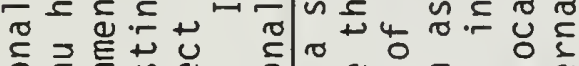

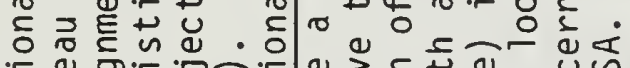
$\because$ o.

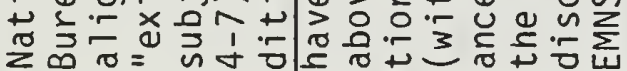

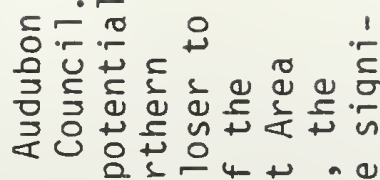

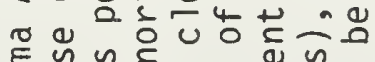
至

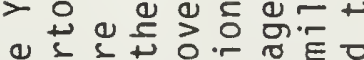

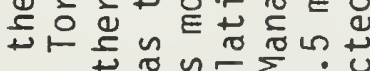

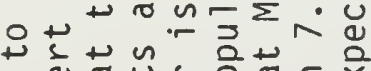
d

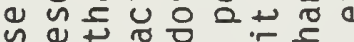

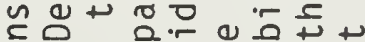

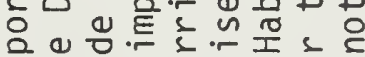

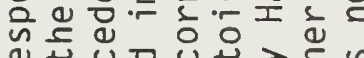

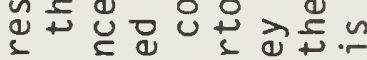

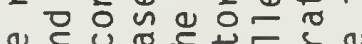

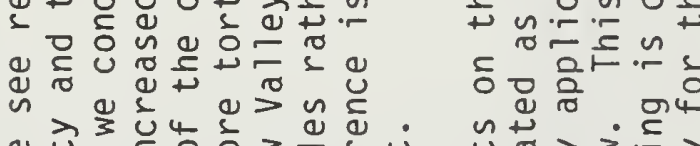

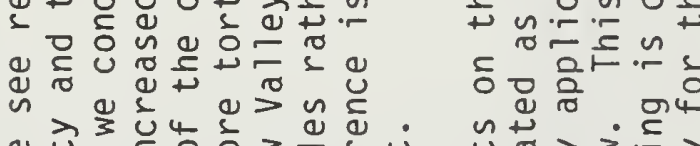

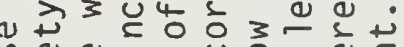
ये⿺辶一兀

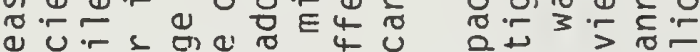

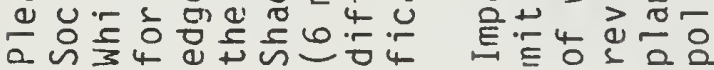

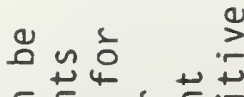

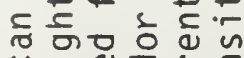

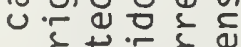
a $\leadsto$

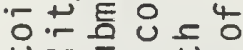

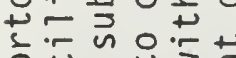

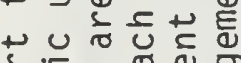
a 4 थ un $=1$ 的

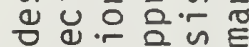
西石 的苑 थ

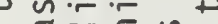

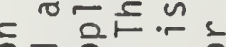
윰

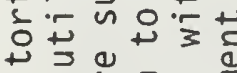

我它|

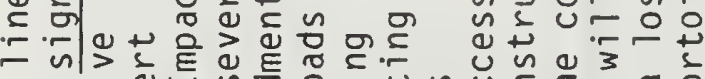
ร

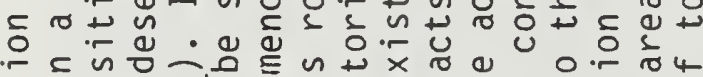

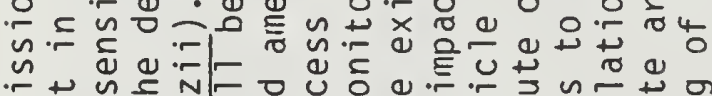

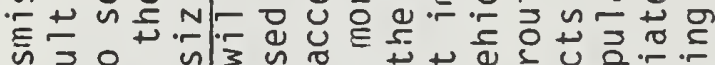

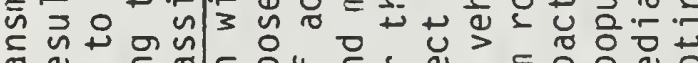

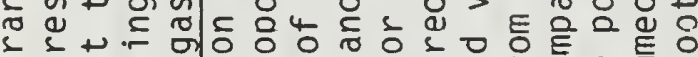

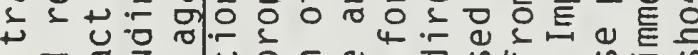

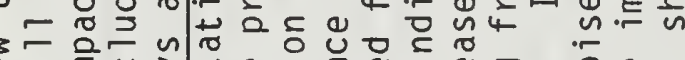

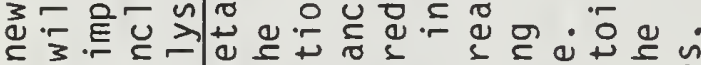
了.下

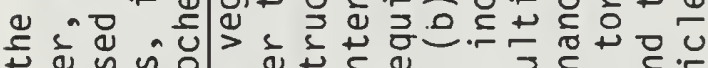
a n ñ $>$ \&

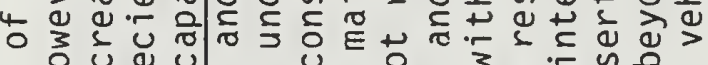
o U d u u

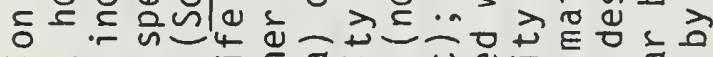

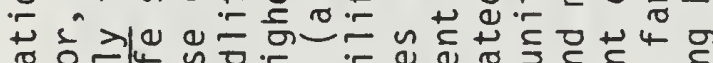

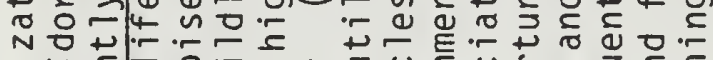

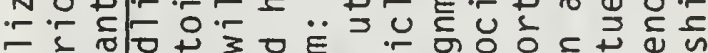

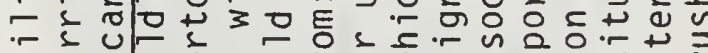

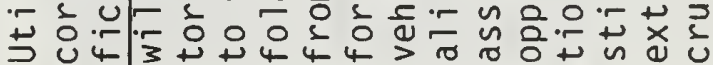




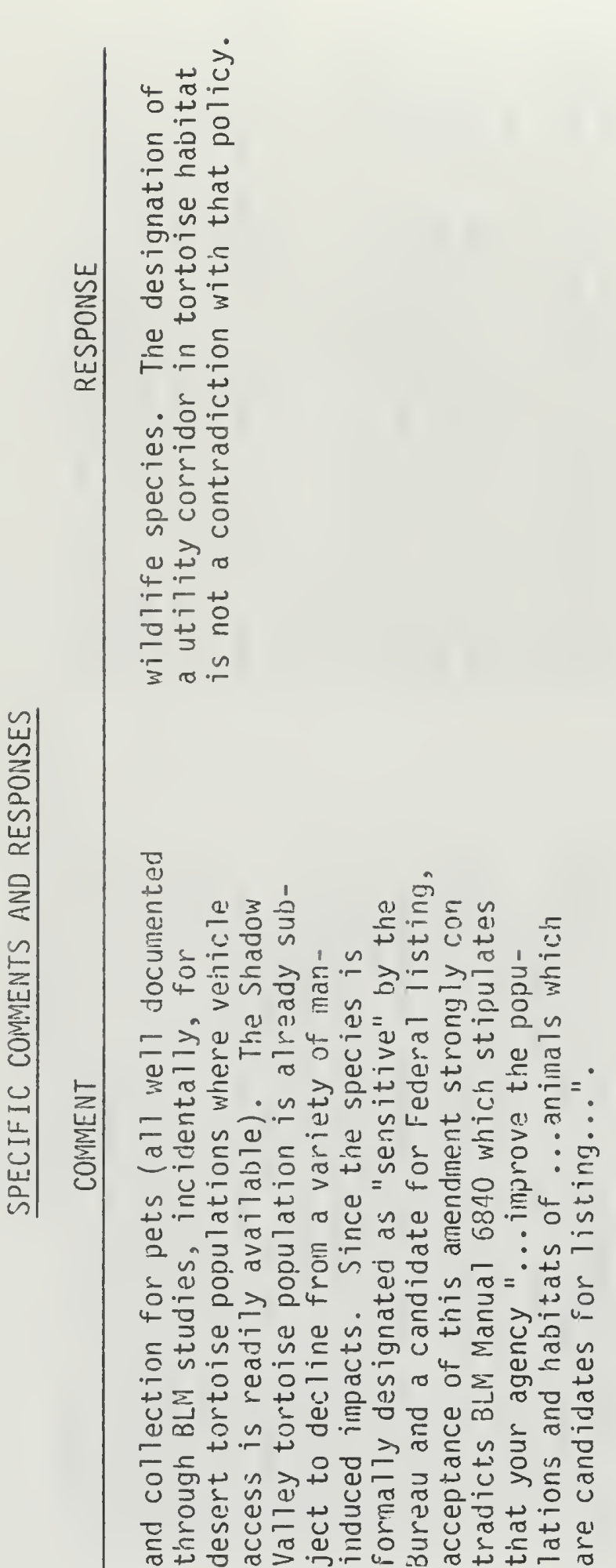

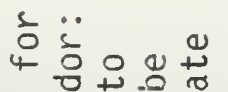

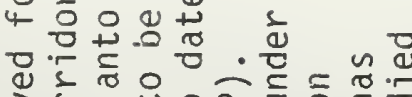

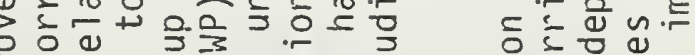

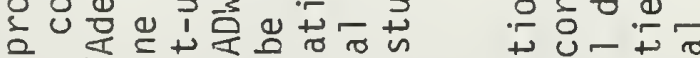

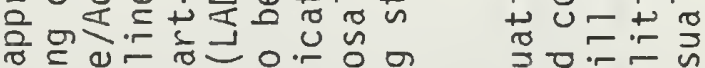
o. ᄃ

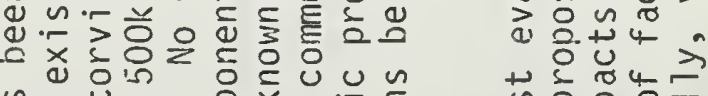

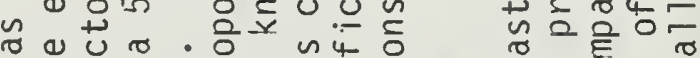
ฮิ

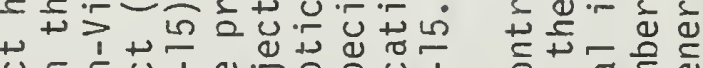
U.

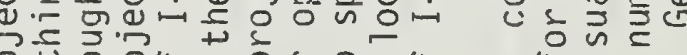
О厂

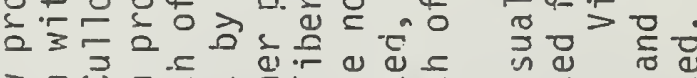
उ

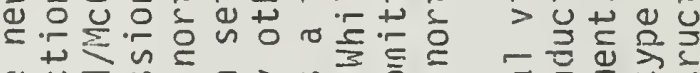

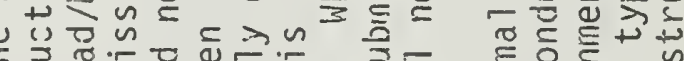

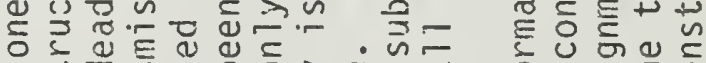

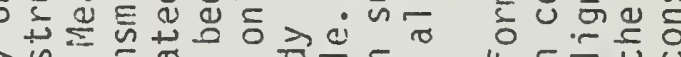
$\lambda$ थ

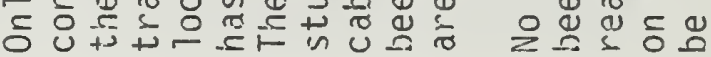

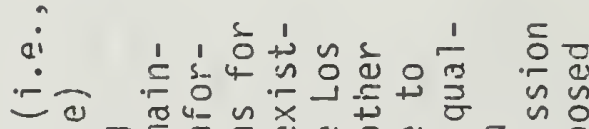

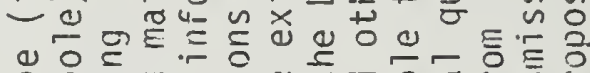

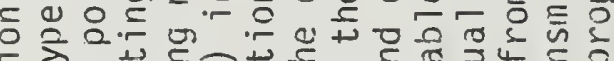

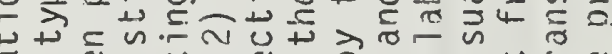

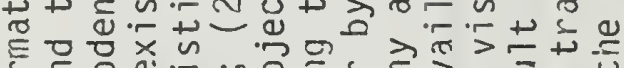

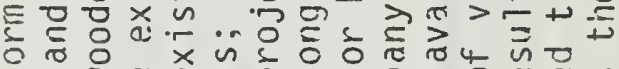

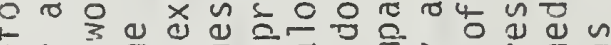
. a

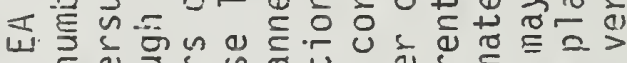

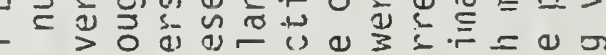
б

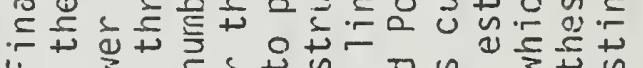
u

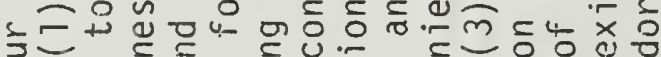
ว $>\ddot{0} \cup$ ㄴ

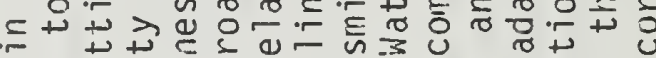

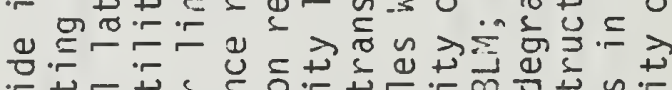

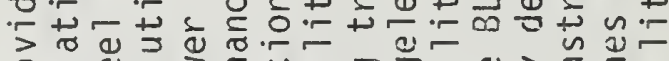

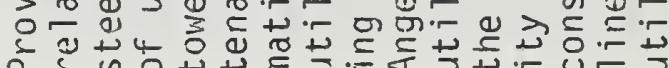




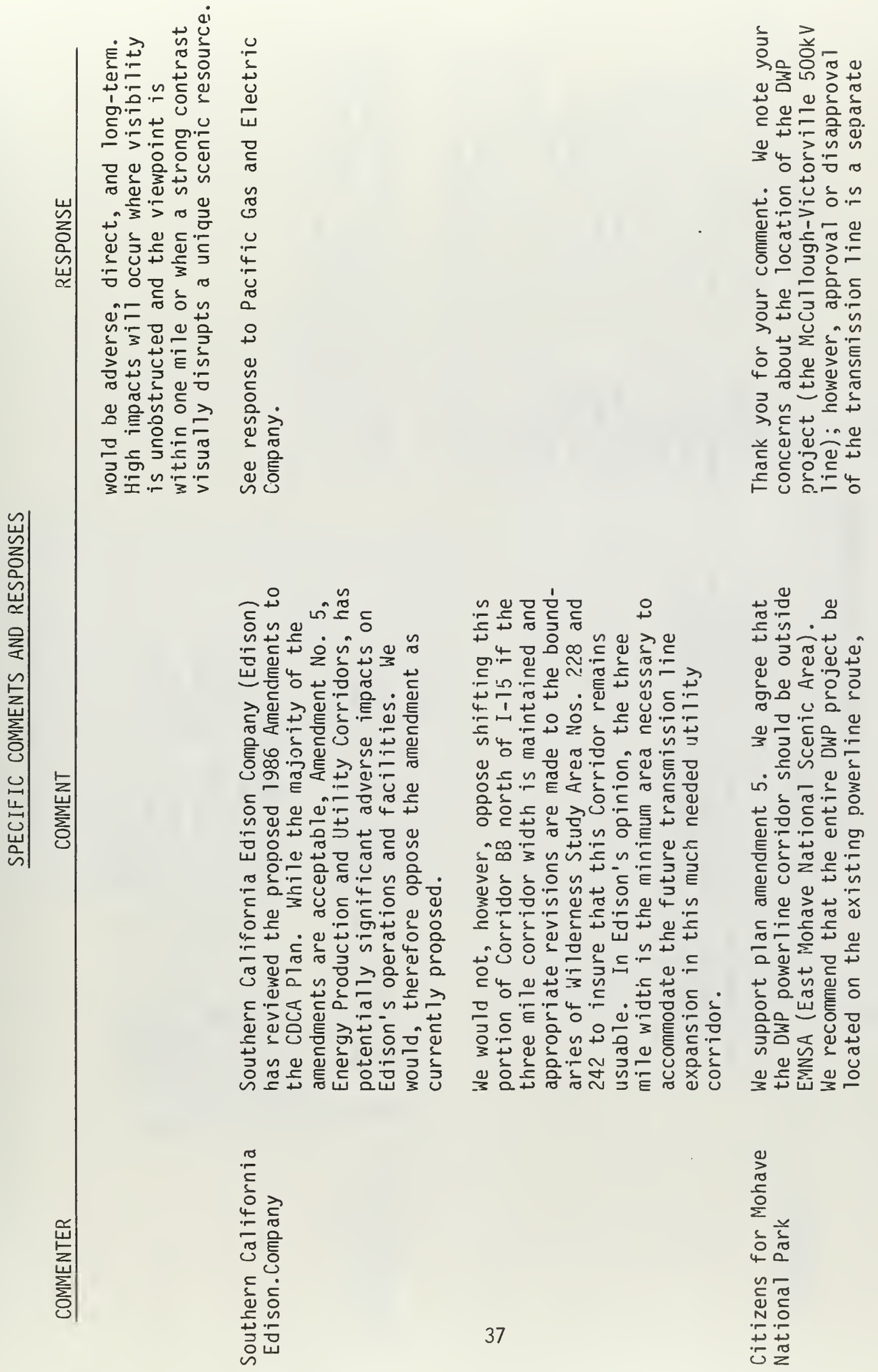




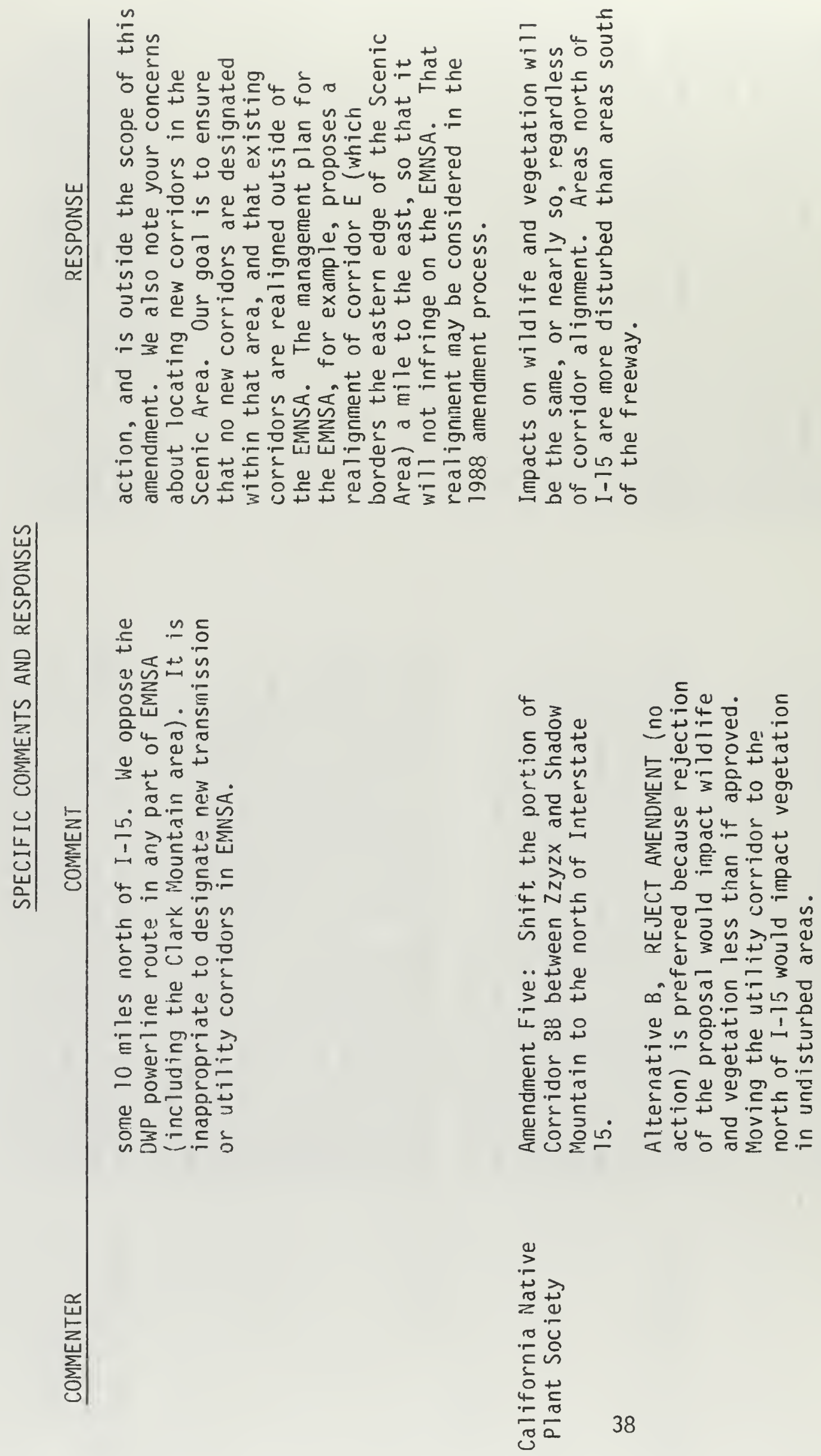



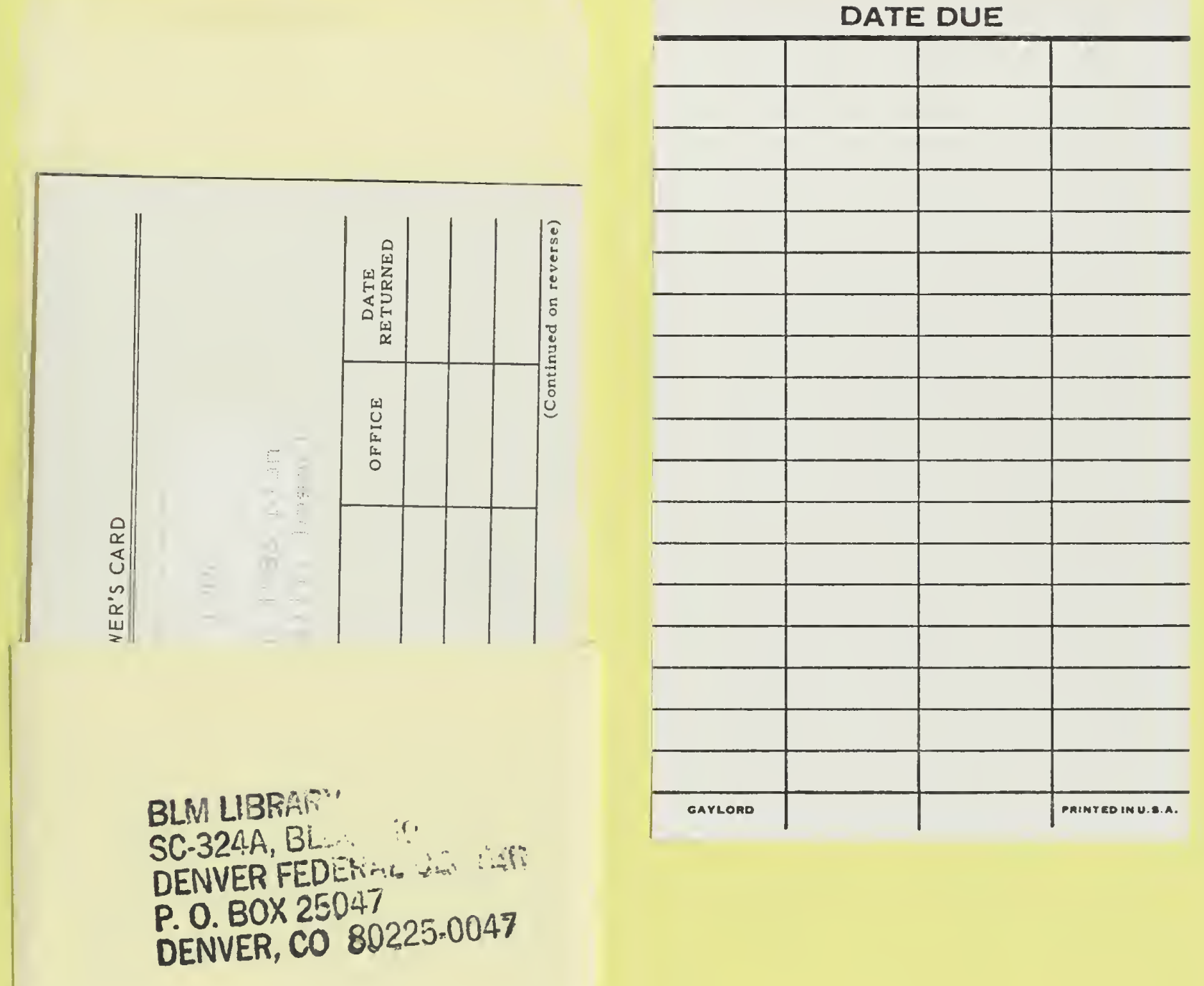
